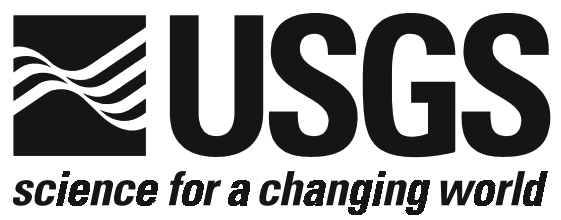

\title{
ANALYSIS OF MAGNETOTELLURIC PROFILE DATA FROM THE RUBY MOUNTAINS METAMORPHIC CORE COMPLEX AND SOUTHERN CARLIN TREND REGION, NEVADA
}

\author{
by \\ Philip E. Wannamaker ${ }^{1}$, William M. Doerner ${ }^{2}$, \\ John A. Stodt ${ }^{1}$, Timothy L. Sodergen ${ }^{1}$ \\ and \\ Brian D. Rodriguez ${ }^{3}$
}

Open-File Report 02-214

on-line edition

2002

This report is preliminary and has not been reviewed for conformity with U.S. Geological Survey editorial standards and stratigraphic nomenclature. Any use of trade, product, or firm names is for descriptive purposes only and does not imply endorsement by the U.S. Government.

\section{U.S. DEPARTMENT OF THE INTERIOR}

\section{U.S. GEOLOGICAL SURVEY}

\footnotetext{
${ }^{1}$ University of Utah, Salt Lake City, Utah

${ }^{2}$ Quantech Geoscience, Inc., Reno, Nevada

${ }^{3}$ Denver, Colorado
} 


\begin{abstract}
We have collected about 150 magnetotelluric (MT) soundings in northeastern Nevada in the region of the Ruby Mountains metamorphic core complex uplift and southern Carlin mineral trend, in an effort to illuminate controls on core complex evolution and deposition of world-class gold deposits. The region has experienced a broad range of tectonic events including several periods of compressional and extensional deformation, which have contributed to the total expression of electrical resistivity. Most of the soundings are in three east-west profiles across increasing degrees of core uplift to the north (Bald Mountain, Harrison Pass and Secret Pass latitudes). Two shorter lines cross a prominent east-west structure to the north of the northern profile. MT impedance tensor and vertical magnetic field rotations imply a N-NNE average regional geoelectric strike, similar to surface geologic trends. Model resistivity cross sections were derived using a 2-D inversion algorithm, which damps departures of model parameters from an a priori structure, emphasizing the transverse magnetic (TM) mode and vertical magnetic field data. Geological interpretation of the resistivity combines previous seismic, potential field and isotope models, structural and petrological models for regional compression and extension, and detailed structural/stratigraphic interpretations incorporating drilling for petroleum and mineral exploration. To first order, the resistivity structure is one of a moderately conductive, Phanerozoic sedimentary section fundamentally disrupted by intrusion and uplift of resistive crystalline rocks. Late Devonian and early Mississippian shales of the Pilot and Chainman Formations together form an important conductive marker sequence in the stratigraphy and show pronounced increases in conductance (conductivity-thickness product) from east to west. These increases in conductance are attributed to graphitization caused by Elko-Sevier era compressional shear deformation and possibly by intrusive heating. The resistive crystalline central massifs adjoin the host stratigraphy across crustal-scale, subvertical fault zones. These zones provide electric current pathways to the lower crust for heterogeneous, upper crustal induced current flow. Resistive core complex crust may be steeply bounded under the middle of the neighboring grabens and not deepen at a shallow angle to arbitrary distances to the west. The numerous crustal breaks imaged with MT may contribute to the low effective elastic thickness estimated regionally for the Great Basin and exemplify the mid-crustal, steeply dipping slip zones in which major earthquakes nucleate. An east-west oriented conductor in the crystalline upper crust spans the East Humboldt Range and northern Ruby Mountains. The conductor may be related to an inferred ArcheanProterozoic suture or nearby graphitic metasediments, with possible alteration by middle Tertiary magmatic activity. Lower crustal resistivity everywhere under the profiles is low and appears quasi one-dimensional. It is consistent with a low rock porosity $(<1$ vol. \%) containing hypersaline brines and possible water-undersaturated crustal melts, residual to the mostly Miocene regional extension. The resistivity expression of the southern Carlin Trend in the Pinon Range is not a simple lineament but rather a family of structures attributed to Eocene intrusion, stratal deformation and graphitization. Substantial reactivation or overprinting by core complex uplift or extensional events seems likely. We concur with others that the Carlin trend may result in part from overlap of the large Eocene Northeast Nevada Volcanic Field with PrecambrianPaleozoic deep-water clastic source rocks thickening abruptly to the west of the Pinon Range, and projections to the north-northwest.
\end{abstract}




\section{INTRODUCTION}

Northeastern Nevada has experienced a long and complex geological heritage involving numerous modes of tectonic activity. These include Archean-Proterozoic basement terrane accretion, late Proterozoic margin rifting and ocean formation, deposition of a thick miogeoclinaleugeoclinal sedimentary succession, protracted compressional deformation, two episodes of calcalkaline plutonism, emplacement of world-class gold deposits, spectacular development of metamorphic core complex exposure, and the present day regional morphology dominated by Great Basin normal faulting (Armstrong, 1982; Snoke et al., 1990, 1997; Burchfiel et al., 1992; Zoback et al., 1994; Dickenson, 2001). Diverse processes of global significance have acted to form these structures but many remain poorly understood. In the list of such are the control by pre-existing basement structures on subsequent deformation and gold deposition, the geometry and thermal effects of overthrust development, the possibility of fluids in the crust and magma near the Moho, the geometry and kinematics of core complex formation, and the depth extent of major normal faulting.

We have acquired about 150 magnetotelluric (MT) data soundings in north-central Nevada centered on the Ruby Mountains core complex profiles (Figure 1), using in-house instrumentation. The effort initially was aimed at probing the form and state of the core complex itself and was carried out in collaboration with wide-angle seismic investigations (Stoerzel and Smithson, 1998; Satarugsa and Johnson, 1998, 2000a,b). Station layout is primarily as three, eastwest profiles across areas with varying degrees of core complex uplift (Bald Mountain, Harrison Pass and Secret Pass profiles in Figure 1). There also are two north-south profiles, which attempt to quantify apparent east-west structures (Cross-Secret and Peko Hills profiles). The MT data are argued to resolve several key components of the complex history and state of the crust relevant to the core complex uplift and latest extension, and of several previous phases of structural development, which often are cryptic at the surface.

Crustal resistivity (or its inverse, conductivity) appears strongly affected by grainboundary fluids or solid phases such as graphite if interconnected over distances comparable to the resolving kernels of diffusive electromagnetics $(\sim 100 \mathrm{~m}$ at $500-1000 \mathrm{~m}$ depth, several kilometers in the lower crust) (Haak and Hutton, 1986; Wannamaker and Hohmann, 1991; Jones, 1992; Shankland et al., 1997; Wannamaker, 2000). While there have been numerous previous studies of rift resistivity structure (Jiracek et al., 1995; Wannamaker et al., 1997a), ours highlights the cumulative effects of multiple tectonic episodes on current resistivity structure. We will show that fluids and graphite both have strong roles in certain domains of the study area and both illuminate important processes in thermal state and deformation. We make use of electrical marker horizons (organic shales) in the Paleozoic sedimentary section and fluidization/ alteration of fault structures to infer geologic cross sections of 70-110 km total length across the core complex and adjacent ranges. This is done in concert with existing geological, seismic and drilling data.

Mines of north-central Nevada have produced over 25,000,000 oz of gold through 1996 from disseminated, hydrothermal ore bodies in the Paleozoic sedimentary section (Teal and Jackson, 1997). These deposits tend to lie in lineaments, principal ones being the Carlin and Battle Mountain-Eureka-Getchell trends. While deposit alignment can be persuasive to the human eye, the trends have been difficult to establish in terms of intra-deposit geological structures or geophysical signatures. Potential fields, MT, and isotope geochemistry have been applied elsewhere in the region to try to uncover independent expressions and causes of these trends 
(Grauch et al., 1995; Hildenbrand et al., 2000; Tosdal et al., 2000; Rodriguez and Williams, 2001, 2002). Because the emplacement of these deposits involves permeable pathways and, in some cases, association with super-mature (graphitic) organic strata either as anticlinal seals or geochemical controls (Kuehn and Rose, 1995; Ilchik and Barton, 1997), the possibility that these ore deposit trends may be verified with deep EM surveys, i.e., MT, is investigated further here.

\section{GEOLOGICAL SETTING OF NORTH-CENTRAL NEVADA AND THE RUBY MOUNTAINS AREA}

The field area lies within east-central Nevada in the Great Basin extensional province (Figure 1). Tectonism was initiated with Archean and early Proterozoic cratonization southward from the Uinta Arch, followed by middle Proterozoic epicratonal sedimentation, and then by late Proterozoic passive margin rifting and foundering of the sialic crystalline basement (Burchfiel et al., 1992; Karlstrom et al., 2001). Based on isotopic compositions, the Archean-Proterozoic suture (Cheyenne Belt) may lie in the northern Ruby Mountains-East Humboldt Range near our northerly SCP MT profile (Lush et al., 1988; Wright and Snoke, 1993) (Figure 1). Phanerozoic sedimentation resembled a U. S. Atlantic-style passive margin (west-facing) with a miogeoclinaleugeoclinal sedimentary section (mainly carbonate rocks over clastics) developing from late Proterozoic through Devonian time over rifted, crystalline basement (Poole et al., 1992). Total sedimentary thicknesses abruptly increase from about $1 \mathrm{~km}$ in western Utah to nearly $15 \mathrm{~km}$ in central Nevada (Stewart, 1980).

Mid-Paleozoic compression events, primarily the Antler orogeny (Roberts Mountain allochthon), disrupted miogeoclinal sedimentation and deposited clastic sediments eastward in a foreland basin (Burchfiel et al., 1992; Giles and Dickinson, 1995; Silberling et al., 1997). Notable here are the organic-rich shales of the late Devonian Pilot and early Mississippian Chainman Formations (Ransom and Hansen, 1993; Carpenter et al., 1994; Saucier, 1997). The roughly 50 Myr duration of the Antler deformation caused thickness, facies and age variations of the Chainman Formation especially from northwest to southeast in eastern Nevada (Trexler and Nitchman, 1990; Trexler et al., 1995). These shales are the principal hydrocarbon source rock of the Great Basin and are variable in their maturity (graphitization) due to subsequent thermotectonic events (Foster and Vincellette, 1991). Following the Antler orogeny, a near continuum of second-order disturbances in central Nevada is recognized persisting through Permian time culminating in the Sonoma orogeny (Trexler et al., 1991, 1995; Snyder et al., 1991; 1995).

Andean-margin type conditions developed in the Mesozoic with widely-scattered calcalkaline plutonism and probable compressional orogeny (Elko event; Thorman et al., 1992; Elison, 1996). Triassic-early Cenozoic time witnessed the Sevier orogeny, including eastward vergent folding and thrusting, metamorphism, and uplift of eastern Nevada and western Utah (Armstrong, 1968; Burchfiel et al., 1992; Taylor et al., 2000). In contrast to spectacular, longdistance thin-skinned thrusting of the Wyoming-Utah frontal belt, more local and mid-regional orogenic events define the central Nevada Elko-Sevier deformation (Thorman et al., 1991; Hudec, 1992; Carpenter et al., 1993a; Camilleri and Chamberlain, 1997; Taylor et al., 2000). Late Mesozoic and early Cenozoic shallow-water basin sedimentation occured mainly in the northcentral part of our study area and the resulting deposits include the Eocene organic-rich Elko Formation (Solomon, 1992; van de Kamp and Samoun, 1992; Satarugsa and Johnson, 2000b).

Mid-Cenozoic calc-alkaline activity sweeping in east-west belts from the north accompanied intense local extension and uplift. The intrusives are argued to provide the heat engine for Carlin-type deposit formation (Thorman et al., 1991; Christiansen and Yeats, 1992; 
Axen et al., 1993; Brooks et al., 1994, 1995; Henry and Ressel, 2000). During the waning phases of this magmatism about 25-40 Ma, the Ruby Mountains metamorphic core complex was unroofed and exposed by the progressive development of a low angle detachment fault system (Snoke et al., 1990, 1997). Remnants of this detachment dip shallowly to the west-northwest along almost all of the crystalline core uplift, leading to projections that the crystalline exposures may have come, in a relative sense, from lower crust as far west as beneath the Pinon Range toward the south and the Adobe Range toward the north (Howard, 1992; Newman and Witter, 1992). However, some of the middle and lower crust now exposed is believed to have flowed ductilely into the uplift area from the south, not from across strike (MacCready et al., 1997).

Basin and Range extension began about $17 \mathrm{Ma}$ in central Nevada with widely-spaced, listric and planar normal faulting (Thorman et al., 1991; Christiansen and Yeats, 1992; Zoback et al., 1994). These gave way to larger, listric normal faults believed to sole into deeper, low-angle extensional faults to form the present ranges (Wernicke, 1992). Since about $10 \mathrm{Ma}$, crustal thinning, seismicity and basaltic to bimodal volcanism have concentrated near the margins of the Great Basin region and remain active to the present, leaving a subdued or near-dormant level of extensional deformation in the central Great Basin (Wannamaker et al., 1997a,b; 2001).

COCORP deep crustal seismic profiling from the $40^{\circ} \mathrm{N}$ traverse of the North American Cordillera crosses the south central part of the MT coverage (Figure 1). The COCORP seismic data show a subhorizontal and laterally persistent zone of Moho reflections, implying a flat and continuous Moho at $\sim 32-35 \mathrm{~km}$ depth in the area of the MT transects (Hauser et al., 1987). The Moho reflectors are overlain by a zone of subhorizontal reflections and refractions, which thins from the west to the east. This layer is interpreted by Potter et al. (1986) to represent a zone of uniformly horizontally stretched and intruded lower crust. Where the seismic line crosses the axis of the southern Ruby Mountains at Overland Pass, crustal reflections show relatively low coherency apart from short, gently west-dipping reflectors in the upper crust tentatively associated with core complex detachment and subhorizontal patches of reflectivity in the middle crust and deeper (Hauser et al., 1987). The line also crosses at the point of minimal complex uplift, less even than that at the latitude of our southerly MT profile at Bald Mountain. In the area of the Butte Mountains to the east (Figure 1), the upper crust has remained rather intact and little extended. Given the nearly flat Moho, this implies that the lower crust there has preferentially thinned (Hauser et al., 1987).

Multicomponent, wide-angle seismic recording was carried out as a complement to this MT survey over a $95 \mathrm{~km}$ long, N-S profile along the east side of the Ruby Mountains (Stoerzel and Smithson, 1998; Satarugsa and Johnson, 1998, 2000a,b) (Figure 1). Travel-time inversion by Stoerzel and Smithson (1998) implied that $V_{p}$ and $V_{s}$ increase with depth, and laterally from south to north. Maximum mafic underplating of 6-7 km thickness in the southern Ruby Mountains (Harrison Pass area) versus 12-15 km in the north (Secret Pass area) interpreted from the velocities contributed to core uplift while Moho depth increased from about 32.5 to $34.5 \mathrm{~km}$ to the north. In contrast, from the same transect data Satarugsa and Johnson (2000a) modeled an essentially layered velocity section from north to south with negligible mantle-derived underplating of the core uplift. Nevertheless, the relatively high velocities in both studies are consistent with only small $(<\sim 1$ vol. \%) fluid contents. This is in accord with the regional-scale MT modeling of the southerly Bald Mountain line discussed by Wannamaker et al. (1997b). We will investigate this conclusion further in more detailed interpretation of all three profiles. 


\section{MAGNETOTELLURIC DATA ACQUISITION AND PROCESSING}

\section{Brief Definitions for Magnetotellurics}

The MT method uses naturally occurring electromagnetic (EM) wave fields as sources for imaging the electrical resistivity structure of the Earth (Vozoff, 1991; Jiracek et al., 1995). Because the fields have a distant origin and the Earth-air impedance contrast is high, the incident EM waves usually are treated as planar in geometry and propagating vertically downward. In the conducting Earth, EM waves travel diffusively, such that high frequency (short period) waves penetrate a relatively short distance while low frequency (long period, $>100$ s) waves may reach the mantle.

The scattered electric $(\mathrm{E})$ and magnetic $(\mathrm{H})$ vector fields returned to the surface by buried structure may have arbitrary polarization relative to the incident fields. This requires a tensor relationship between the measured fields as a function of frequency or its inverse, period (T), denoted for the horizontal components through

$$
[\mathrm{E}]=[\mathrm{Z}][\mathrm{H}]
$$

where $\mathbf{Z}$ is the $2 \times 2$ complex impedance. The individual impedance elements typically are transformed into an apparent resistivity $\left(\rho_{a}\right)$ and an impedance phase $(\varphi)$ for presentation and modeling. On a uniform half-space of resistivity $\rho, \rho_{a}=\rho$ and $\varphi=45^{\circ}$. For more complex structures, $\rho$ a versus $T$ usually resembles a smoothed version of $\rho$ versus distance below the measurement. The phase $\varphi$ tends to be proportional to slope of $\rho_{a}$ versus T, and thus is more reflective of spatial gradients in subsurface resistivity. These primary data in turn are transformed to constrained resistivity models by the process of inversion, specified in the model construction section below.

Over two-dimensional (2-D) structures where one of the measurement axes is parallel to geoelectric strike (x here by convention), the diagonal entries of $\mathbf{Z}$ are zero (Vozoff, 1991). In this situation, the MT response separates into two independent modes. These are the transverse electric (TE) mode, where $\mathrm{E}_{\mathrm{x}}=\mathrm{Z}_{\mathrm{xy}} \mathrm{H}_{\mathrm{y}}$ and electric current flows parallel to strike (x-axis), and the transverse magnetic (TM) mode, where $E_{y}=Z_{y x} H_{x}$ and current flows perpendicular to strike (y-axis). Analogously, a 1 × 2 tensor $\mathbf{K}_{\mathbf{z}}$ relates the vertical and horizontal magnetic fields through

$$
\left[\mathrm{H}_{\mathrm{z}}\right]=\left[\mathbf{K}_{\mathbf{z}}\right][\mathrm{H}]
$$

For a 2-D Earth, $\mathrm{K}_{\mathrm{zx}}=0$ and $\mathrm{K}_{\mathrm{zy}}$ reflects the distribution of current flowing along strike (TE mode).

\section{Survey Design and Geoelectric Strike Definition}

Because the dominant horst-graben morphology of the north-central Nevada is oriented approximately north-south, we concentrated our MT soundings in east-west transects in an attempt to achieve well-resolved sections through the region (Figure 1). In addition to the sites on the three E-W transects, there are two shorter MT profiles running N-S across the Secret Pass line to constrain apparent E-W trending structures there. Almost all MT data were 
recorded by the University of Utah dual-site system, with induction coils (EMI, Inc.) and $\mathrm{Pb}$ $\mathrm{PbCl}_{2}$ electrodes separated by $100 \mathrm{~m}$ used to measure the magnetic and electric fields, respectively. The typical recording period range was $0.005-1000 \mathrm{~s}$, with bandwidth, gain and run-time settings of each site configured from a central recording location (truck) via digital FM radio telemetry. Synchronized recording allows each site to be used as a reference for the other (Vozoff, 1991), to enable noise with a correlation distance less than the site separation to be suppressed. EM field spectra with multiple coherencies $<0.75$ typically were rejected, and MT response functions and errors were computed using formulas of Gamble et al. (1979) and Stodt (1983). Further details can be found in Doerner (1996). The eight western MT sites in the Pine Valley-Crescent Range area of the long, central profile HRP (Figure 1) were donated by Zonge Engineering and Research and were processed following Sutarno and Vozoff (1989). A right-handed coordinate system with $+\mathrm{z}$ downward and $\exp (i \omega \mathrm{t})$ time dependence $(\omega=$ angular frequency) are assumed for both collected and modeled data.

Although the north-south trend of regional geology in our study area suggests that the dominant, large-scale geoelectric orientations should be similar, we tested this by estimating geoelectric strike directions from principal axes of $\mathbf{K}_{\mathbf{z}}$, plus principal impedance directions corrected for near-surface distortions, for all three transects (Figure 2). Note that impedance principal directions exist every $90^{\circ}$, and thus do not unambiguously denote strike, but one of the directions should nearly parallel strike estimates from $\mathbf{K}_{\mathbf{z}}$ if structure is approximately twodimensional.

For the impedances, rather than perform a traditional decomposition (Groom and Bailey, 1989), principal impedance axes were estimated following Bahr (1988) who noted that phases of the impedance elements in each column of the tensor should become equal to the regional phases in the regional strike and dip directions. Thus, we estimate these principal directions by incrementally rotating $\mathbf{Z}$ until the quantity $\Delta$ is minimized, defined by

$$
\Delta=|\varphi x x-\varphi y x|+|\varphi x y-\varphi y y|
$$

Each phase estimate possesses a standard deviation $\varphi_{\mathrm{ij}}$, so that each phase $\varphi_{\mathrm{ij}}$ is considered to lie in an probability interval of $\varphi_{\mathrm{ij}} \pm \varepsilon_{\mathrm{ij}}$. The difference $\Delta$ hence is considered insignificantly different from zero when the phase intervals of both terms above overlap for a particular coordinate direction. The entire coordinate rotation angle range over which this may occur is a permissible strike estimate. The procedure was carried out at each period at each site for $1^{\mathrm{o}}$ rotation increments, and the permissible strike range was recorded. Checks were implemented for changes in quadrant of phase values with rotation. The integer values of permissible strike for each datum were normalized by the number of values and binned into $10^{\circ}$ sectors for plotting in Figure 2. For $\mathbf{K}_{\mathbf{z}}$, just the nominal strike angles for which $\mathrm{K}_{z y}$ was maximized were binned and plotted.

Overall, both the principal impedance axes and the $\mathbf{K}_{\mathbf{z}}$ strike directions for the Bald Mountain and Harrison Pass profiles in Figure 2 are compatible with a north-south strike direction (x-axis). Some scatter is evident due to limited phase anisotropy in the data and a relatively weak vertical $\mathrm{H}$-field except at certain locations. Across the Secret Pass profile, however, the $\mathbf{K}_{\mathbf{z}}$ strike direction and impedance axes appears more WNW-ESE, or about normal to surficial Basin and Range strike. Given the overall behavior, a fixed north-south strike definition for all data values on the Bald Mountain and Harrison Pass profiles is adopted for modeling here. Modeling coordinates for the Secret Pass line are maintained at the original magnetic north $\left(\mathrm{N} 15^{\circ} \mathrm{E}\right)$ utilized in the field due to the trend of the profile, apparent slight 
clockwise rotation of Great Basin morphology in this area, and the orientation of the cross strike feature discussed later.

\section{RESISTIVITY MODEL CONSTRUCTION}

While the study area in north-central Nevada shows a north to NNE-oriented geoelectric trend, it is not purely 2-D. To minimize errors in 2-D models caused by possible 3D effects, we emphasize subsets of the MT data (defined below), which are relatively robust in the 2-D assumption. Subsequently, we produce 2-D models through regularized inversion techniques intended to minimize model artifacts possibly caused by data noise.

In our 2-D interpretation, we primarily utilize the TM mode data ( $\rho_{y x}$ and $\varphi_{y x}$ ) with fixed strike directions as defined previously for several reasons. First, the TM mode over a 2-D structure includes galvanic (boundary charge) terms in its formulation, as must the corresponding observed response across our transects (Wannamaker et al., 1984; Wannamaker, 1999). These terms are not contained in 2-D TE responses, and so the effects of along-strike (3D) variations in field results are fundamentally underrepresented in the TE mode. Also, while TM mode impedance anomalies along profiles over either 2-D or 3-D, laterally confined bodies are zero-mean, no such long-wavelength character can be defined for the TE (xy) mode data (Torres-Verdin and Bostick, 1992; Wannamaker, 1999). Hence, large-scale biases in model depths or resistivities are possible in 2-D TE modeling if 3-D effects are present, but are suppressed in modeling the TM mode if along-profile coordinates such as in this study are used. Third, 2-D modeling of fixed-axis, TM mode data across 3-D conductors can yield remarkably accurate cross-sections, even for profiles which are not closely centered over the body, due to the inherently galvanic nature of the anomalies in both 2-D and 3-D cases (Wannamaker, 1999).

In addition, the vertical magnetic field response $\mathrm{K}_{z y}$ is included in the inversions because the effects of variations along strike on this quantity are relatively mild compared to those on the nominal TE mode impedance (Wannamaker, 1999). In particular, anomalies in $\mathrm{K}_{z y}$ are band-limited and do not suffer from static shift. Their amplitudes are a measure of alongstrike current flow and thus serve as a partial substitute for the TE impedance in a joint TM-TE inversion. We make limited use of the TE phase $\varphi_{x y}$ over the Pinon Range on the central profile to resolve the conductance (conductivity-thickness product) of a steeply dipping, upper crustal layer within the southern Carlin Trend in the Pinon Range (Figure 1).

The inversion algorithm producing the model resistivity cross sections uses the finite element (FE) simulator and Jacobians of Wannamaker et al. (1987) and DeLugao and Wannamaker (1996), and damps model variations from an a priori structure (Tarantola, 1987; Mackie et al., 1988). This approach smooths the models by reducing and broadening resistivity contrasts. Comparisons with explicit curvature-damping schemes (e.g., Rodi and Mackie, 2001) are given in Wannamaker et al. (2002). A Gauss-Newton solution for the parameter iterative step is used. Model parameters are $\log _{10} \rho$, while data are $\log _{10} \rho_{a}$, linear $\varphi$, and dimensionless $\operatorname{Re}\left(\mathrm{K}_{\mathrm{zy}}\right)$. Total mesh size for the three east-west profiles was 341 nodes wide by 52 deep, usually with four element columns per MT site. Given the second-order approximation for auxiliary quantities in the FE solution (DeLugao and Wannamaker, 1996), typically there are only two columns of parameters per MT site in the FE mesh. As depth increases in the FE model, parameter thicknesses and widths expand to help equalize parameter influence on the MT response according to EM scaling (Grant and West, 1965), so the FE parameter grid is not rectilinear throughout. Inversions were ended when misfit reductions per iteration became 
$<0.05 \%$.

Inversion models for all three profiles are assembled in Figure 3. All show a vertical exaggeration of 2 in the upper $10 \mathrm{~km}$. With limited exceptions, the data included in all three inversions were the TM mode ( $\rho_{y x}$ and $\varphi_{y x}$ ) and the vertical magnetic field $K_{z y}$ at all sites and periods, considered above to be more reliable for the 2-D assumption. Fits of model responses, and test calculations in specific areas are described below for the individual profiles. The $a$ priori (and starting) model is the same for each line and is plotted as a column to the left of each model section. It is a purely 1-D resistivity variation computed using an algorithm equivalent to the 2-D approach above and the characteristic sounding curve data for the central Great Basin derived by Wannamaker et al. (1997b). This curve in turn was generated by integrating the TM (yx) mode impedance along the 42 MT sites of the Bald Mountain profile (Figure 1) which approximately filters out heterogeneous variations spanned by the profile (Torres-Verdin and Bostick, 1992).

\section{Bald Mountain Profile}

We begin by examining the southernmost profile of 42 MT sites in the Diamond RangeBald Mountain-Butte Range district, collected over five valleys and four ranges (Figures 1 and 3). This line is south of the main area of Ruby Mountains core uplift and is intended to represent a background structure upon which core complex deformation was imposed. The stratigraphic section spans the middle Cambrian to the Cretaceous with intrusion by Jurassic and early Oligocene plutons in the central and eastern portions (Nutt et al., 2000). In the Diamond Range and western Huntington Valley in the west, Elko or Sevier era compression from the west defines the eastern limit of the Eureka fold-and-thrust belt. Interpreted geologically here is a pronounced syncline, possible overthrust motion along the northern extension of the Pancake thrust, and later, possibly Tertiary dismemberment by higher-angle normal faulting, as interpreted structurally to the south in the Pancake Range (Smith et al., 1991; Carpenter et al., 1993a,b). A broad anticlinal arch is inferred across the central region accentuated by more localized uplift of the Bald Mountain area. The latter in turn may represent a subdued, southern extension of the uplifted Ruby Mountains core complex (Rigby, 1960). The synclinal Butte Mountains comprise the eastern portion of the profile.

Our resistivity model in Figure 3 shows lateral variations in the upper to middle crust with characteristic spatial wavelengths of 10-15 km. The most resistive variations occur under Bald Mountain itself and the Maverick Springs Range nearby to the east, both of which have experienced substantial plutonism. High resistivity is seen under the eastern Diamond Range as well, and a small outcrop of Tertiary intrusive is mapped $\sim 10 \mathrm{~km}$ north of our line there (Figure 1). Between resistive bodies lie steeply dipping zones of higher conductivity which, when taken in aggregate with the resistors, define an average broadscale resistivity as represented by the $a$ priori 1-D section. If the resistive regions represent intrusives, then in the more conductive zones must lie the remaining sedimentary strata which are substantially deformed by the intrusive, overthrust and extensional events. In the upper 3-4 km under the Diamond Range is a pronounced synclinal and anticlinal conductive layer responsible for low $\rho_{y x}$ over a broad period range and high $\varphi_{y x}$ at short to middle periods. The layer weakens in conductance to the east and we examine it further below.

Below $\sim 15 \mathrm{~km}$ depth, the resistivity structure shows only mild departures from the initial, increasingly conductive 1-D variations of the a priori depth profile (Figure 3 ). To a large degree, these may result from the inversion regularization, where diffuse extensions of the Diamond and 
Maverick Springs Range resistors increase deep resistivity slightly. Directly under Bald Mountain and the Maverick Springs Range is an exception in showing slightly enhanced conductivity relative to the starting model. An electrical connection between the steep, upper and middle crustal conductors and the deep crustal, quasi-layered medium appears to some extent in all three inversion sections of Figure 3. Tests presented with the Harrison Pass line suggest these connections permit anomalous currents from upper crustal lateral heterogeneities to bleed vertically to the deep crust and allow apparent resistivity values over the resistive crustal blocks, including the core complex uplift, to fall sufficiently at long periods. This effect of vertical current channeling has been interpreted in numerous other orogenic environments (e.g., Park et al., 1991, 1996; Wannamaker et al., 1991, 1997a, 2002). The low resistivities of the deep crust are controlled by the physical state of the hydrothermal or magmatic system there as discussed more fully in our synthesis section.

In Figure 4 are given the observed and computed principal apparent resistivity, impedance phase, and tipper elements along the Bald Mountain profile, in the coordinates defined previously. The sites are numbered sequentially from west to east. Generally, the TM mode fit to the data is good throughout both $\rho_{\mathrm{yx}}$ and $\varphi_{\mathrm{yx}}$ pseudosections. The overall root-mean-square (RMS) misfit $\varepsilon R$ was $\sim 4.2$ for the joint inversion. A value of 1 is ideal, but higher $\varepsilon R$ is typical due to nonGaussian behavior in the data (Parker and Booker, 1996) and inevitable 3-D effects. Shortscale variations between computations and data often are the result of observational scatter. For $30<\mathrm{T}<200 \mathrm{~s}$, lateral variation in observed $\varphi_{\mathrm{yx}}$ with a spatial scale of $3-5 \mathrm{~km}$ appears statistically significant and indicates a limited level of 3-D data distortion which is beyond that assumed in the impedance strike estimation method previously.

Both real and imaginary parts of $\mathrm{K}_{\mathrm{zy}}$ were inverted for Bald Mountain, although only $\operatorname{Re}\left(\mathrm{K}_{\mathrm{zy}}\right)$ is plotted in Figure 4. The fit generally is good also although the computed anomaly may be slightly weaker than the observed in the Diamond Range. There are visible anomalies in $\operatorname{Re}\left(\mathrm{K}_{\mathrm{zx}}\right)$ which are not explicitly considered in the 2-D inversion. A rather weak variation at $\mathrm{T}=$ $\sim 3 \mathrm{~s}$ in $\operatorname{Re}\left(\mathrm{K}_{\mathrm{zx}}\right)$ from the Maverick Springs Range eastward signifies a conductor with E-W elongation lying south of the profile probably 3-10 km based on average apparent resistivities and skin depth estimates (Vozoff, 1991). Positive variation in $\operatorname{Re}\left(\mathrm{K}_{\mathrm{zx}}\right\}$ under the Diamond Range suggests trends of upper crustal conductors in the model there are somewhat west of north. An intense, single-site anomaly at very short periods near the profile center yields at longer periods to one mainly in $\operatorname{Re}\left(\mathrm{K}_{\mathrm{zy}}\right)$, which was inverted and appears mostly due to strong horizontal current channeling near the Huntington Valley-Bald Mountain area structural interface.

The TE impedance data ( $\rho_{x y}$ and $\varphi_{x y}$ ) were not included in the inversion and the TE response of the Bald Mountain inversion model of Figure 3 does not fit the TE data well (Figure 4). The discrepancies appear characteristic of known finite strike effects upon the TE mode caused by electric boundary charges at resistivity boundaries off-profile (Wannamaker et al., 1984, 1999), and justify our decision to exclude this mode from formal interpretation. Several relatively narrow lows in $\rho x y$ persist to arbitrarily long periods and are unfittable by a 2-D model, which tends to generate very smooth TE responses at long periods. Under the Diamond Range especially, computed $\rho_{x y}$ is much higher and $\varphi_{x y}$ is much lower than observed, also consistent with finite strike extent of the folded conductor of the upper crust. We consider it likely that this conductor in reality has reached a nearly static limit for $\mathrm{T}>\sim 10 \mathrm{~s}$ so that long period TE phase recovers to values more like that of the TM mode which was modeled. This appears characteristic of long periods of the entire profile.

We focus now on the primary conductive fold structure in the upper 3-4 km of the crust 
under the Diamond Range. Utilizing borehole and surface geologic constraints (Dobbs et al., 1994), the conductor is identified as the combined shales of the late Devonian Pilot $(\sim 100 \mathrm{~m}$ thickness) and early Mississippian Chainman Formations ( $\sim 300 \mathrm{~m}$ thick) (hereafter lumped as the Chainman Shales), with the intervening Joanna Limestone ( $\sim 60 \mathrm{~m}$ thickness) not separately resolved. In particular, the conductive unit subcrops beneath the westernmost Diamond Range where these formations come to surface (Plate 1 of Dobbs et al., 1993). The conductance of this organic-rich sequence under the Diamond Mountains, where it is folded and faulted, is a factor of 5-10 higher than under central Huntington Valley, and such high conductance is not seen further to the east either in our inversion section (Figure 3). A local region of low resistivity outcropping in southeastern Huntington Valley (Figure 3) probably is graben alluvium; regional gravity data (Ponce, 1992) show a 10-15 mgal Bouguer low here, and detailed gravity followup and modeling by Dobbs et al. (1994) indicate alluvial thicknesses of up to $1 \mathrm{~km}$.

Hence, as an alternate representation of the resistivity structure, forward models were generated for the soundings of the western portion of the profile where the conductive layer thickness is constrained to be that of the combined Pilot-Chainman sequence, with its internal conductivity and geometry determined by trial-and-error fitting (Figure 5). The "best-fit" forward model also reproduces the observations well, though a bit less so than the inversion due to fewer degrees of freedom. This model shows the conductance of the Chainman Shales to diminish markedly to the east of the Diamond Range also. The model exhibits a sequence constriction under sites 7-8 (visible as well in the inversion model) which we will interpret later to reflect subsequent down-to-west normal faulting. Alternate model "Continuous" in Figure 5 shows that lack of such a constriction causes an inhomogeneous response, which is much too great under the eastern Diamond Range to agree with the data. In addition, a response, which grossly underfits the response is generated if the conductance under the Diamond Range is reduced to that under Huntington Valley (Constant $\mathrm{C}$ in Figure 5). Electrical properties of the Chainman Shales apparently have been altered under the Diamond Range, possible reasons for which will be discussed.

\section{Harrison Pass Profile}

Our transect across the central Ruby Mountains is the longest of the three $(>100 \mathrm{~km})$ and contains 57 sites (Figure 1). It crosses the core complex over the Harrison Pass pluton, an early Oligocene granodiorite (Barnes et al., 2001), where the gradient in core uplift from south to north is greatest (Hudec, 1992). Most Mesozoic deformation is believed to be Jurassic in age, with Sevier deformation being minor or non-existent in the area. Simple down-dip projection of the core complex mylonitic detachment westward implies that Ruby Mountains core crust in this area originated beneath the Pinon Range to the west (Howard, 1992; Figure 1). Several deep drillholes $(>3,000 \mathrm{~m})$ for petroleum exploration were completed on both the west and east side of the range and penetrate late Paleozoic rocks in relatively undeformed state under Huntington Valley and Ruby Valley (Schalla, 1992; Fink and van de Camp, 1992). Over $1 \mathrm{~km}$ of early Cenozoic lacustrine sediments lie under Huntington Valley as well (op. cit.), and the stratigraphy has been extrapolated across the valley with released seismic reflection data (Reese, 1986).

The Harrison Pass resistivity model in Figure 3 also was derived by joint inversion of the TM mode and vertical magnetic field data, but we also included the TE mode impedance phase for the western-most 18 sites at short and middle periods (marked in the response pseudosections Figure 6) to help resolve Carlin Trend structure locally. The model shows lateral variations in the upper to middle crust of similar spatial scale to the Bald Mountain profile but of somewhat 
different character. Very high resistivities are seen under the Ruby Mountains, central Pinon Range, and east central Ruby Valley. The Ruby and Pinon Range resistors are separated under Huntington Valley by a major zone of steeply dipping crustal-scale conductors in the $5-15 \mathrm{~km}$ depth range. A narrow, conductive, near-vertical conductor occurs directly under the eastern Pinon Range from 2-6 km depth, which causes a noticeable TE phase peak not obvious in the TM phase. A thick conductor under Pine Valley several kilometers down deepens to $\sim 10 \mathrm{~km}$ depth beneath high resistivities of the Cortez Range. On the east flank of the Ruby Mountains, a vertical conductor from near surface to $20 \mathrm{~km}$ depth separates the Ruby Mountains and Ruby Valley crustal resistors. Under the eastern Ruby Valley and Medicine Range, lower resistivity layer-like features can be seen extending eastward at about 3 and $8 \mathrm{~km}$ depth, like that seen under the Butte Mountains of the southern Bald Mountain profile (Figure 3). Below $20 \mathrm{~km}$ depth, a broad-scale lower crustal conductor is modeled similar to those of the initial guess and under the southern profile.

Pseudosections of our MT data and inversion calculations for the Harrison Pass profile generally compare well (Figure 6). The overall root-mean-square (RMS) misfit $\varepsilon \mathrm{R}$ was $\sim 3.7$ for the joint inversion. Perhaps most obvious are the very high $\rho_{y x}$ values over the Ruby Mountains themselves plus very low values under Huntington Valley, caused by the high contrast between core rocks and valley fill. In contrast, $\varphi_{x y}$ over the valley shows low values at middle periods while $\rho_{x y}$ rises due to higher resistivities under the fill. The valley-core rock contrast is corroborated by the $\mathrm{H}_{\mathrm{z}}$ response, which is quite strong on this side of the range. High TM mode $\rho_{y x}(\mathrm{~T}>1 \mathrm{~s})$ and low $\varphi_{y x}(0.1-3 \mathrm{~s})$ under the Pinon Range are evidence for the high resistivities in a middle crustal zone broadening with depth. The TM data are reconciled with high $\varphi_{x y}(\mathrm{~T} \cong$ $1 \mathrm{~s})$ and a minimum in $\rho_{x y}(T \cong 3 \mathrm{~s})$ through the narrow vertical conductor there from $2-6 \mathrm{~km}$ depth, mentioned above (Figure 3). Such TE-TM behavior often is explained by narrow conductors at depth constituting a macro-scale electrical anisotropy (Wu et al., 1993; Wannamaker et al., 2002). The effect is exemplified in sounding form in Figure 7, which shows the pronounced dip in $\rho_{x y}$ and peak in $\varphi_{x y}$, while simultaneously exhibiting steeply climbing $\rho_{y x}$ and a low in $\varphi_{y x}$. This behavior is characteristic of six soundings across the Pinon Range and is not seen elsewhere in our study area. Continued falloff in the TE $\rho_{x y}$ at the longest periods may be the effect of finite strike of mid-crustal scale conductors (Wannamaker, 1999) or perhaps due to large-scale anisotropy of the lower crustal conductive layer.

High resistivities under western Ruby Valley are brought out by the low $\varphi_{y x}$ and rising $\rho_{y x}$ around $\mathrm{T}=1-3 \mathrm{~s}$ (Figure 6). The computed $\operatorname{Re}\left(\mathrm{K}_{\mathrm{zy}}\right)$ is somewhat greater than observed here, consistent with a shallowing of valley fill nearby to the south (Ponce et al., 1996) and the positive values of observed $\operatorname{Re}\left(\mathrm{K}_{\mathrm{zx}}\right)$ (3-D effect, cf. Wannamaker, 1999). There also is a negative computed $\operatorname{Re}\left(\mathrm{K}_{\mathrm{zy}}\right)$ for $\mathrm{T}=1-10 \mathrm{~s}$ under Pine Valley (Figure 6) not seen in the data. Unfortunately, no vertical field data were recovered from the soundings over Pine Valley except for the second and fourth most western sites, so we cannot assess the fit here. The computed $\varphi_{y x}$ is less anomalous than the data at long periods under Pine Valley, suggesting that the strong mid crustal conductor in the inversion model still is not conductive enough. A modest visual disagreement between observed and modeled TM phase under Huntington Valley at long periods ( $\mathrm{T}>20 \mathrm{~s}$ ) is primarily due to poor statistical quality of the data just there.

Apart from the limited selection of $\varphi_{x y}$ used for inversion, computed TE results disagree with the observed at several locations (Figure 6). The most noticeable perhaps is under Pine Valley, where the very high observed $\varphi_{x y}$ and low $\rho_{x y}$ imply finite strike extent of the midcrustal conductor here (Wannamaker, 1999). Similar finite strike is deduced for Huntington 
Valley also, so that observed $\varphi_{x y}$ is not as low as computed and observed $\rho_{x y}$ preserves low values to the longest periods. This is consistent as well with gravity data showing our profile passes near the Bouguer gravity minimum for this valley (Ponce et al., 1996). This character of disagreement between observed and computed 2-D TE quantities due to along-strike electric boundary charges has long been recognized in computer simulations of Basin and Range structures and caution is required in TE mode interpretation (Wannamaker, 1999). However, it also would be very useful to have profile data extended to the west on this profile to help quantify the substantial mid-crustal conductivity in this region.

The steep conductors under Huntington Valley and between the Ruby Mountains and Ruby Valley constitute electrical connections from the upper crustal structure to the lower crust which allow secondary currents induced by the graben sediments and other conductive heterogeneity to bleed to the lower crust rather than be forced through the resistive rocks of the range. To test the requirement for this, we imposed a thin but high-resistivity ( $\sim 5000 \mathrm{ohm}-\mathrm{m})$ layer-like unit from the deep Pinon Range resistor to that under western Ruby Valley in our inversion section (marked in Figure 2) in order to break the electrical connection with the deep crust. The inversion was re-run using this modified section as an a priori model to examine whether changes in resistivity structure elsewhere can be defined which compensate for the presence of the imposed resistive, mid-crustal layer (cf. Park et al., 1996; Wannamaker et al., 2002a). Although the resulting section partially compensated for the imposed mid-crustal resistive layer with somewhat lower resistivity at upper-middle crustal levels, serious disagreement appears between data and computations compared to the fit of the preferred model of Figure 2 (Figure 5). This is characteristic of numerous soundings over the core complex portion of the profile. Although this is a 2-D model, and we should remain aware of possible conductive pathways across strike and out of the plane of the section, the TM mode data are relatively robust to variation along strike (Wannamaker, 1999) so that electrical connections from the upper to lower crust are compelled by our results. The data do not appear compatible with a simple, low-angle deepening of resistive core complex crust to points under the Pinon Range.

\section{Secret Pass Profile}

This line of 39 sites and $81 \mathrm{~km}$ length passes across the most uplifted, and perhaps most studied, core complex crust of the three profiles (Valasek et al., 1989; Snoke et al., 1990, 1997; Wright and Snoke, 1993). Geological relations indicate a complicated, pre-uplift lower crustal intrusive history from late Jurassic through Cretaceous time, all superimposed in the Secret Pass area upon an isotopically-defined, east-west tectonic boundary separating Archean basement to the north from Proterozoic rocks to the south (Figure 1). Late Eocene extrusives are seen near the southern end of the East Humboldt Range and high-temperature hydrothermal alteration of late Oligocene age is observed towards its north end north of our profile (Peters and Wickham, 1994; McGrew et al., 2000). Mid-Miocene rhyolites have been dated near the northernmost tip of the range (Snoke et al., 1997). As near Harrison Pass, the main mylonitic detachment zone is exposed extensively along the west side of the range and dips westward. Projections by Newman and Witter (1992) placed presently exposed crystalline core complex beneath the Adobe Range some $40 \mathrm{~km}$ west prior to uplift.

The Secret Pass model cross section in Figure 3 also was produced through joint inversion of the TM mode and vertical magnetic field data and shows features in common with both Bald Mountain and Harrison Pass profiles. The central core complex rocks are resistive and are 
bounded on the east under Clover Valley by a vertical conductor extending to the deep crust. Lower resistivities are seen as well to depth under the conductive sediments of Lamoille Valley though to a less pronounced degree. Perhaps the most remarkable feature of this section is the arcuate conductor under the East Humboldt Range in Figure 3, which extends eastward from the surface to $\sim 6 \mathrm{~km}$ depth and connects with the vertical conductor below Clover Valley. A lesser, near-vertical conductor is seen extending to the middle crust within central Secret Pass. Below 20 $\mathrm{km}$ depth, the broad-scale lower crustal conductor appears again which is similar to those of the initial guess and under the Bald Mountain and Harrison Pass profiles.

Pseudosections of our MT data and computations for the Secret Pass profile appear in Figure 9, and the inverted data generally show reasonable fits by the TM mode and $\operatorname{Re}\left(\mathrm{K}_{\mathrm{zy}}\right)$ inversion computed responses. The overall root-mean-square (RMS) misfit $\varepsilon R$ was $\sim 5.6$ for the joint inversion and reflects some lack of fit of $\operatorname{Re}\left(\mathrm{K}_{z y}\right)$ at the East Humboldt Range-Clover Valley transition, and of $\varphi_{y x}$ under the Peko Hills-Lamoille Valley transition. Seen again are very high TM mode $\rho_{y x}$ values over the Ruby Mountains themselves plus very low values under Lamoille Valley, similar to the analogous structures of the Harrison Pass line. Similar also, computed TE mode $\varphi_{x y}$ over the valley shows much lower values than observed at middle periods while $\rho_{x y}$ is rising more rapidly, evidence again in concert with the gravity that Lamoille and Clover Valley sediments become thinner off-profile (3-D effect). A striking anomaly of high $\varphi_{y x}$, coherent across several sites in the eastern Secret Pass area, is observed from 1-100 s and signifies the arcuate conductor inverted under the East Humboldt Range (Figure 3). That there is little evidence of this in $\rho_{x y}$ and $\varphi_{x y}$ is consistent with this conductor diminishing to the north and connecting to Ruby Valley to the south, so that currents channeling northward may inflate $\rho_{x y}$ and diminish $\varphi_{x y}$ here. Observed and computed $\operatorname{Re}\left(\mathrm{K}_{\mathrm{zy}}\right)$ show good overall agreement across the sections, although the negative anomalies flanking western Clover Valley and the eastern part of the Spruce Mountain Range may be underfit somewhat.

To a degree far greater than the other two profiles, the Secret Pass MT transect exhibits a strong, cross-strike resistivity structure paralleling the transect. This is evident from the large values of $\operatorname{Re}\left(\mathrm{K}_{\mathrm{zx}}\right)$, which is sensitive to east-west current concentrations (Figure 9), in the 1-20 $\mathrm{s}$ period range. This anomaly persists across most of the profile, possibly including neighboring valleys and ranges. Most values of $\operatorname{Re}\left(\mathrm{K}_{\mathrm{zx}}\right)$ are negative (blue colors) but, westward across Lamoille Valley toward the Adobe Range, the sign changes to positive (red). The sign change is suggestive that we may cross the conductor in the valley center of Lamoille Valley. This conjecture presumes that a single structure is the cause, and we will evaluate that here. To help quantify the properties and origin of this cross strike conductor, two short profiles of MT sites were taken perpendicular to the main Secret Pass transect (Figure 1). One of these ("Cross Secret") was placed over the core complex rocks within Secret Valley in an attempt to escape influence of the conductive alluvium of Clover and Lamoille Valleys plus the difficulty of private land access along the range fronts. The second profile lies along the crest of the Peko Hills and eastern flank of the Elko Hills, and mainly overlies the thick Phanerozoic sedimentary section.

Inversion cross sections and MT response pseudosections for both lines appear in Figure 10. For the Cross Secret line, the negative values of $\operatorname{Re}\left(K_{z x}\right)$ in the $1-10$ s period range persist at a nearly constant level across all sites. Local anomalies extending to shorter periods also occur near the north and south ends. For 2-D inversion, quantities $\rho_{x y}$ and $\varphi_{x y}$ were treated as TM mode data and $\operatorname{Re}\left(\mathrm{K}_{\mathrm{zx}}\right)$ as TE data in a joint analysis. This approximation is considered feasible since we are concerned mainly just with structure of the upper and middle crust and some ESE-WNW structural trends are evident within Secret Pass (Valasek et al., 1989). Two sites of the main Secret Pass line are included for a total of 8 soundings in the profile. The 1-D a priori structure 
was obtained by 1-D inversion of the integrated xy-mode impedance for the 8 sites, constrained against the regional 1-D profile used in the three main transects (Figure 3). The inversion responses fit the data well (Figure 10) and show that the main anomaly in $\operatorname{Re}\left(\mathrm{K}_{\mathrm{zx}}\right)$ can be reproduced by a shallow, tabular conductor in the upper $5 \mathrm{~km}$ situated 5-10 km north of the Secret Pass profile. It appears to lie within crystalline rocks of the northern Ruby Mountains core complex. Shallow resistivity variations under the profile sites fit shorter-period, small-wavelength data anomalies, but the main conductivity structure does not lie within Secret Pass itself. The subhorizontal, tabular shape helps keep $\operatorname{Re}\left(\mathrm{K}_{\mathrm{zx}}\right)$ nearly constant across the 8 sites, but additional sites along the massif to the north would be helpful in resolution. Test calculations show that this upper crustal conductor has minor influence upon $\rho_{\mathrm{yx}}$ and $\varphi_{\mathrm{yx}}$ at sites of the main Secret Pass transect, and the similarity of middle and lower crustal structure on this transect compared to that of Harrison Pass and Bald Mountain (Figure 3) suggest that the 2-D inversion of the Secret Pass data is reasonably accurate. Other studies have indicated that $\mathbf{K}_{\mathbf{z}}$ anomalies often are approximately separable (e.g., Dosso and Meng, 1992; Wannamaker et al., 2002).

Inversion cross sections and response pseudosections for the Peko Hills line are quite different from Cross Secret (Figure 10). For 2-D inversion, quantities $\rho_{x y}$ and $\varphi_{x y}$ again were treated as TM mode data, while $\varphi_{\mathrm{yx}}$ and $\operatorname{Re}\left(\mathrm{K}_{\mathrm{zx}}\right)$ were treated as TE data in the joint analysis. Lying over thick sedimentary sections, apparent and inverted resistivities are relatively low although, at depths below 5-10 km, some of this may be due to "sideswipe" of the xy-mode data by conductive sediments of Lamoille Valley or by a possible thick conductor like that west of the Pinon Range on line HRP as suggested by Rodriguez and Williams (2001). Nevertheless, a few features stand out. First, high resistivity in the upper $5 \mathrm{~km}$ appears in the northern portion of the profile. It may indicate cryptic late Eocene volcanic intrusion since we observed intense surficial silicification of sedimentary rocks there during the MT surveying (not shown on Coats, 1987). Additional low resistivity in the middle crust of the central portion of the profile reproduces the high values of $\varphi_{x y}$ and $\varphi_{y x}$ and falling $\rho_{x y}$ in the 10-100 s period range, although some of this may be an artifact of finite E-W strike extent of the proposed overlying intrusives (cf. Berdichevsky et al., 1998). However, test computations with this section indicate that the positive anomaly in $\operatorname{Re}\left(\mathrm{K}_{\mathrm{zx}}\right)$ from $0.1-10 \mathrm{~s}$ period in the central portion of the profile, which is the cross-strike expression of the corresponding anomaly noted earlier at the west end of the main Secret Pass transect (Figure 9), is due merely to conductive sediments in the upper $2 \mathrm{~km}$ of the central portion of the Peko Hills line (just west of "sc" in Figure 10). This feature thus has no apparent connection with basement structure which was the cause of the anomaly in $\operatorname{Re}\left(\mathrm{K}_{\mathrm{zx}}\right)$ on the Cross Secret line. Given this conclusion, we cannot argue that the negative anomaly in $\operatorname{Re}\left(\mathrm{K}_{\mathrm{zx}}\right)$ at the eastern end of the Secret Pass transect in the Spruce Mountain Range is necessarily associated with the basement structure of Secret Pass either, although further MT surveying could establish this.

\section{SYNTHESIS AND GEOLOGICAL CORRELATIONS}

An interpretive correlation of resistivity variations with geological formations, structures, intrusions and hydrothermal activity is summarized in Figure 11. Auxiliary information important in the constructions comes from deep seismic investigations, potential field geophysics, structural mapping and petrology, drilling, and thermal maturation studies. We present each transect in turn, but point out common features to help provide some unity in the total structural picture of the Ruby Mountains core complex, the central Great Basin extensional subprovince generally, and 
the pre-Miocene heritage of compressional tectonics and plutonism.

\section{Bald Mountain Profile}

The $10-15 \mathrm{~km}$ scale lateral variation in the upper to middle crust of our resistivity model for this line (Figure 3) is interpreted to reflect late Mesozoic to present disruption of preexisting albeit overthrusted Paleozoic and late Precambrian strata, principally by possible Jurassic-Cretaceous and mid-Tertiary intrusion and extension (Brooks et al., 1995; Elison, 1996; Nutt et al., 2000) (Figure 11). Relatively undeformed stratigraphic properties are represented towards the east end of this and the other two transect models (Long Valley-Butte Valley areas), where quasi horizontal units of moderately low resistivity (40-100 ohm-m) extend eastward at depths of 3-4 km and 8-10 km (Figures 3 and 11). From stratigraphic sections in Stewart (1980), these likely denote Chainman Shales (upper conductor) and perhaps Lower Cambrian Pioche Shale (lower conductor) within more resistive clastic and carbonate sections. Chainman Shales were intersected also at depths of 3.6 and $4 \mathrm{~km}$ in the Ruby Valley Franklin-1 borehole (Fink and van de Kamp, 1992; Satarugsa and Johnson, 2000b) (Figure 1). Chainman organic units are known conductors even if sub-mature (Wannamaker et al., 1997a) and some graphitization of Pioche Shale in eastern Nevada also has been recognized (J. Welch, pers. comm.).

Approaching the Maverick Springs Range, these units truncate against more resistive material at a near-vertical conductor allowing vertical electric current flow. Given that Jurassic and Mid-Tertiary intrusives are observed at the surface or in drillholes in the Bald MountainMaverick Springs Range area and northern Diamond Range (Figure 1) (Stewart and Carlson, 1978; Nutt et al., 2000), these locally high resistivities are believed to reflect subsurface intrusives (e.g., Jones, 1992; Wannamaker et al., 1997a). The lower resistivity material bounding intrusive areas should mainly be the disrupted and altered remains of the thick stratigraphic section, but the degree of deformation below several $\mathrm{km}$ depth is difficult to judge. Our model is not inconsistent with previous COCORP seismic surveying in the area, which passed over locally less uplifted crust through Overland Pass to the north of this transect, and which resolved primarily weak subhorizontal reflectors of possibly late Miocene age in the middle crust and deeper. Rodriguez and Williams (2001) model a lower-resistivity, subvertical unit in the Bald Mountain area from sparser MT data which may correspond to our steep conductor under Mooney Basin (Figure 2).

The very conductive folded layer in the upper crust of the Diamond Range is established from an equivalent structural setting to the south (Carpenter et al., 1993a,b) as Chainman Shales, with the syncline cored by clastics of the Diamond Peak and Newark Valley sequences (Perry, 1995). Based on comparable structures to the south in the Eureka district, the age of folding may be early Mesozoic, an early expression of Sevier overthrusting (Taylor et al., 2000). In the upper 3-4 km, the variations in conductance of the Chainman Shales (factor of 10-30, Figures 3 and 5) far exceed variations in thickness of the formations, which may thin by about a factor of two from west to east across our MT profile (Sadlick, 1995). In studies north of the profile in Huntington Valley, Hazlett et al. (1992) and Inan (1993) observe that Chainman strata are over-mature and graphitized in the Pinon and Diamond Ranges to the west, are marginally mature in Huntington Valley and southern Ruby Mountains, and are sub-mature to the east in the Butte Mountains (Table 1). In southern Huntington Valley locally, the Chainman Shales are submature (Dobbs et al., 1994).

These works imply that organic shale conductance in our profile correlates with 
hydrocarbon maturation, even though total organic content of this shale is higher in the east (Hazlett et al., 1992) (Figure 11). Inan (1993) notes that the degree of variation of maturity appears too great in the Diamond Range area to be explained by subsurface burial alone, and that a correlation with overthrust deformation is evident. The correspondence in Figure 5 of high layer conductance with tight folding suggests graphitization occurred during Elko or Sevier age overthrust deformation rather than during later Cenozoic volcanism (cf., Foster and Vincelette, 1991). This appears to be supported by the abrupt change in conductance at the updip projection of the Pancake thrust as projected northward from Carpenter et al (1993a,b). Boerner et al. (1996) review experiments showing that shear deformation can catalyse graphitization at relatively low temperatures compared to uniform pressure conditions. This appears applicable to our data set because the Diamond Range is not interpreted to have undergone appreciable burial and metamorphism in its history (Dobbs et al., 1993; Carpenter et al., 1993a). Overthrust motion along the projected Pancake thrust under site 10 (Figure 5) is insufficient to disconnect the Chainman sequence, but we interpret the shale to be nearly disconnected by later normal faulting under the eastern Diamond Range below sites 7-8 (Carpenter et al., 1993b).

For depths beyond $\sim 20 \mathrm{~km}$ in the crust, the interpretation of physical state remains similar to that of Wannamaker et al. (1997b) and Wannamaker (2000). Constraining the geotherm independently and assuming a predominantly metaigneous lower crust of high metamorphic grade, low resistivity here $(\sim 20 \mathrm{ohm}-\mathrm{m})$ appears consistent with hypersaline brines near the midcrust to possible undersaturated melting conditions near the base of the crust $(\sim 35 \mathrm{~km})$. Fluid mechanisms of conductivity are prefered because both late Proterzoic and Cenozoic plutonic rocks imply deep crustal $\mathrm{f}\left(\mathrm{O}_{2}\right)$ (oxygen fugacity) which is too high for graphite stability except for temperatures less than about $500^{\circ} \mathrm{C}$ (Christiansen et al., 1986; Carmichael, 1991; Van Schmus et al., 1993; Parkinson and Arculus, 1999). If fluid interconnection is efficient along mineral grain edges, brine contents of only 0.1-0.2 vol. \% are required and appear compatible with theoretical fluid residence times (Frost and Bucher, 1994). This contrasts with the actively extending eastern Great Basin of western Utah, where much lower resistivities imply a higher bound on fluid content (0.4-0.5 vol. \%) and more deformable rheologies (Wannamaker et al.,1997b). Resistivity values increase into the uppermost mantle of our study area, but still are lower than compatible with solid-state conduction in olivine-dominated rocks (Duba and Constable, 1993) and point to a small ( $\sim 1$ vol. \%) melt fraction probably of alkalic composition (Harry and Leeman, 1995). There may be a rough correspondence between the bottom of the lower crustal conductive layer and the seismic Moho; the lower bound of the conductor is interpreted as a transition (presumably gradational) from interconnected fluid or melt in feldspar-dominated crustal rocks, to a region below of less interconnected or absent fluid in olivine-dominated mantle rocks (Holness, 1996, 1997).

\section{Harrison Pass Profile}

The eastern portion of the Harrison Pass transect resembles that of Bald Mountain with a more-or-less upright section of Paleozoic/Pre-Cambrian miogeoclinal section truncated with a fault zone against resistive rocks associated with the Ruby Mountains crystalline uplift under central Ruby Valley (Figure 11). In the Franklin-1 borehole, Fink and van de Kamp (1992) note that Chainman hydrocarbon source rocks at least locally are overmature, which we suggest may reflect nearby Tertiary magmatism. We do not see evidence for resistive core complex rocks under the Medicine Range, which were interpreted to be nearby to the north (toward Delcer Buttes) from velocity structure by Satarugsa and Johnson (2000b). A second steep crustal-scale 
conductor divides the resistive massif of Harrison Pass essentially at the eastern topographic rangefront. These fault zones allow vertical channeling of electric current induced by the upper crustal, conductive valleys, which cannot easily penetrate the resistive rocks laterally, as tested in Figure 8. Ruby Valley sediments themselves are only moderately conductive but show the highest conductivities to be slightly westward-thickening like the reflection seismic model of Satarugsa and Johnson (2000b). Huntington Valley is of much greater conductivity and thickness and we cross it at its thickest, signifying perhaps the substantial amounts of shallow Eocene lacustrine sediments in the section (Solomon, 1992; Satarugsa and Johnson, 2000b). Property access constraints prevented clear imaging of the eastern valley margin, where fanglomerates of variable thicknesses also may occur (op. cit.).

Under Huntington Valley and Cedar Ridge areas, steep conductive pathways connecting the upper and lower crust are strongly expressed and required by the data (Figure 8). The connections are suggested to be crustal-scale disruption zones having increased pore fluid content and alteration. Alteration may include remobilized, fluid-deposited graphite (Luque et al., 1998; Pasteris, 1999; Wannamaker, 2000) derived presumably from any of the organic shales in the section. Due to the resolving power of diffusive EM and the inversion model gridding, these pathways conceivably could be much thinner and hence consistent with the interpretation of relatively upright Paleozoic strata under Huntington Valley by Schalla (1992). In electrical properties, the Ruby Mountains massif here shows fairly steep lateral bounds, and not an obvious shallow dip westward beneath the Pinon Range (cf. Newman and Witter, 1992; Howard, 1992). If these crustal-scale conductors originate with core complex uplift, our model geometry is more compatible with along-strike or upward deep crustal flow (MacCready et al., 1997), as is seen also in other tectonic regimes worldwide (Axen et al., 1998). However, there may be some further resistivity changes in these zones during Basin and Range era normal faulting and graben formation. Reactivated faults in the lower brittle crust (10-15 km depth) are inferred to exist widely in the Basin and Range and constitute structural anisotropies with some roots perhaps to the Precambrian (Carpenter et al., 1993b). If they are characteristic of the Great Basin, they could act to preserve low effective elastic strength of the crust ( $T_{e}$, Lowry et al., 2000) despite possible secular cooling since the middle Cenozoic (Harry et al., 1993). These imaged faults may exemplify those accommodating slip in the large, normal-faulting events which nucleate at midcrustal depths (Smith et al., 2001).

Under the Pinon Range, the high resistivities ( $>1000 \mathrm{ohm}-\mathrm{m})$ broadening downward from a narrow zone in the uppermost crust are correlated with Eocene intrusive and hybridized rocks (Brooks et al., 1995; Grunder, 1995; Henry and Ressel, 2000), which do not appear disrupted by electrical expressions of fault zones (Figures 3 and 11). Possible buried plutonic rocks here are interpreted from aeromagnetic data as well by Smith and Ketner (1976) and Grauch (1996). In contrast, low resistivities $(<10 \mathrm{ohm}-\mathrm{m})$ immediately flank the resistor in the upper several $\mathrm{km}$. Near-horizontal Chainman Shales overlie the eastern flanking conductor (Iverson, 1992) but its steep attitude suggests either extreme stratal deformation and downsagging as the intrusive entered, or alteration and possible graphite redistributed hydrothermally. Lateral narrowness of this and the conductor 3-7 km down to the west under easternmost Pine Valley was required so that the TM and TE mode phase data here could be fit simultaneously (Figure 7). Compared to the Bald Mountain line, it is harder to interpret distinctions among the overlapping Sevier overthrusting, Eocene intrusion, or even earlier Roberts Mountain (Antler) thrusting as causes of this graphitization. Nearby to the west in Pine Valley in Figure 7, 1 km of late Tertiary graben fill overlies Chainman Shales (Inan, 1993; Hansen et al., 1994), with both units being conductive. However, Chainman properties may be quite variable locally as indicated in local 
electrical surveying in the Tomera Ranch area by Ostrander (1990).

High conductivities also occur broadly over the 2-12 km depth range under Pine Valley and Cortez Range, in contrast to the upper and middle crust to the east under the Pinon Range (Figures 3 and 11). This large resistivity transition takes place in the western reaches of the Paleozoic continental platform, where deep-water eugeoclinal clastic rocks begin (across Adobe Arch of Newman and Witter, 1992). The western section includes substantial thickness of organic shales, which generally are post-mature (Hazlett et al., 1992; Newman and Witter, 1992; Inan, 1993; Inan and Davis, 1994) and are now conductive. The westernmost MT sites cross the Jurassic pluton and volcanics of the Cortez Mountains (Stewart and Carlson, 1978), which appear to be $\sim 5 \mathrm{~km}$ thick and extend somewhat under Pine Valley to the east. The $5 \mathrm{~km}$ resistive depth extent probably represents original pluton or extrusive emplacement thickness since deformation from Sevier age compression is minor (Ketner and Alpha, 1992; Taylor et al., 2000). Especially low resistivity in the $5-10 \mathrm{~km}$ depth range at the western edge of the model lies outside station coverage and is not well constrained, but presumably represents additional graphitized, eugeoclinal rocks. This large conductive region in the western part of our profile may be equivalent to the broad carbonaceous/geothermal conductor modeled to the north by Rodriguez and Williams (2002).

In previous searches for deep crustal controls on Carlin-type mineralization trends in the Great Basin, a strong gravity gradient along the Battle Mountain-Eureka gold trend (BME) to the west has been recognized (Grauch et al., 1995). Hildenbrand et al. (2000) suggest from residual gravity anomalies that the BME and Carlin Trend (CT) bound a higher-mass crustal block. Tosdal et al. (2000), emphasizing isotope geochemistry, define major southeast-trending fault systems under both BME and CT. These are inferred to have started as master normal fault systems during late Precambrian continental margin formation, defining a central Nevada subprovince with highly thinned Precambrian basement and thick sedimentation. Rodriguez and Williams (2001, 2002) interpret a subvertical, crustal scale conductor 5-10 km wide under the BME, and correlate it as a reactivated fault zone with possible Precambrian roots. Modeling of Rodriguez and Williams also shows a narrow conductive fault zone in the upper $10 \mathrm{~km}$ of the crust in the northern Carlin trend to the northwest of our study area.

It is possible that the subvertical conductors under the Pinon Range-Huntington Valley area in Figures 2 and 7 are related to or seeded by early controlling structures dating back perhaps to the Precambrian and have relevance to Carlin Trend deposits. The fault zones mainly lie east of observed deposits where crossed by our line, and come to within a few kilometers of the surface. Hence, if the zones served as channels for deep ore fluids, some westward lateral transport of such fluids up shallow dipping pathways to the deposits appears necessary, and perhaps there are other deposits under the alluvium Nevertheless, we caution that substantial ambiguity in the cause of these conductors may exist. Regarding the upper half of the crust, it seems possible that resistive intrusive rocks and conductive remobilised graphite units could persist northwestward into the central CT where Eocene igneous rocks and organic-bearing strata also occur (Leonardson and Rahn, 1996; Henry and Ressel, 2000). However, it is unclear whether such a resistivity makeup should be unique to the $\mathrm{CT}$, as similar intrusion and alteration might occur at other locations off-trend. The conductive fault zones do not appear fundamentally distinct from those on the east side of the Ruby Mountains under the Harrison Pass and Secret Pass profiles (Figures 2 and 7). The zones primarily may reflect accommodation of the Pinon Range intrusion, or Oligocene core complex uplift or Miocene extension. Much of the pre-existing Precambrian crustal structure would now lie in the conductive lower crust, whose properties under the Pinon 
Range do not differ significantly from other areas of our survey and are believed to reflect the late Tertiary thermo-mechanical regime. Moreover, possible post-Eocene, lower crustal flow laterally (Howard, 1992; Newman and Witter, 1992) could have removed much of the early, deep trend structure and its geophysical expression. We conclude that a unique geophysical lineament representing the Carlin Trend is not required by our data, although perhaps original structures served as pre-conditioning to subsequent Cenozoic deformation responsible for the present-day resistivity expression.

As an alternative model, we suggest that the proximity of the Eocene Northeast Nevada Volcanic Field (NNVF) and the abrupt occurance of ancient, deep-water (eugeoclinal) clastic sediments west of the Pinon Range may be important mineralization factors (Brooks et al., 1995; Henry and Ressel, 2000; Tosdal et al., 2000). The NNVF is the largest and most long-lived group of Eocene centers in Nevada although the bulk of it lies to the northeast of the CT. It defines a major lithospheric heating event for northern Nevada comparable to the SE Nevada-SW Utah volcanic field of Oligo-Miocene time (Perry et al., 1993). A major zone of Precambrian normal fault scarps defines the edge of the miogeoclinal platform, and step increases in ProterozoicPaleozoic eugeoclinal, fine-grained sediment thicknessess occur to the west across the CT (Newman and Witter, 1992) (Figure 11). Such deep-water sediments are conjectured to be sources of scavenged gold worldwide (Phillips and Powell, 1993; Kerrich, 1999; Wannamaker et al., 2002) though usually with orogenic crustal thickening as the heat source for fluids. Overlap of the NNVF and these sources may have generated dilute Au-complexed fluids, which can precipitate gold during transport to shallower depth and down gradients in temperature, pressure, salinity or reduction (Kerrich, 1999). Especially steep gradients may occur at seal breakthroughs to the meteoric regime such as at shales or thrust detachments where many Carlin deposits are found (Kuehn and Rose, 1995; Ilchik and Barton, 1997), and some fluid flow potentially may be influenced by the fault zone itself (Tosdal et al., 2000).

Trend deposit alignment also may be promoted by $\mathrm{N}$ - to NNW-trending, PaleozoicMesozoic anticlines in the region such as the Pinon Range and Post anticlines, which provided structural traps for gold mineralization (Smith and Ketner, 1976; Putnam and Henriques, 1990; Leonardson and Rahn, 1996). However, if deposits in the Bald Mountain-Alligator Ridge district are truly CT-type, then the broad conductive zone we see under Pine Valley and Cortez Range cannot be a complete representation of the source rocks since it does not project southeastward under the Bald Mountain profile. This conductor probably continues southward under Diamond Valley or west of there beneath cover of imbricated thrust sheets of Late Paleozoic and Mesozoic age involving Paleozoic shelf and slope sediments (Domain II of Crafford and Grauch, 2002, this issue). The Bald Mountain host strata in fact are dominantly shelf strata, so on occasion a CT-type must have derived gold from such sediments or directly from the Tertiary magma (Henry and Ressel, 2000). Fewer gold occurences east of the CT in the NNVF may be due to inappropriate deep clastic source rocks or the permeability regime was otherwise unfavorable.

\section{Secret Pass Profile}

The eastern portion of the Secret Pass transect resembles those of both Bald Mountain and Harrison Pass with moderate resistivities of the Paleozoic/Precambrian section truncated by a crustal-scale fault zone against resistive rocks associated with the Ruby Mountains 
crystalline uplift under western Clover Valley (Figures 3 and 11). However, a layer-like disposition to this section is less clear. As with the other transects, the Ruby Mountains massif appears to have steep sides at depth. A shallow dip to the detachment interface is not expressed westward of central Lamoille Valley, in disagreement with Smith et al. (1989). Steep dips are supported by observed $\operatorname{Re}\left(\mathrm{K}_{\mathrm{zx}}\right)$ in Figure 9 where the strong negative anomaly from 1-10 $\mathrm{s}$ terminates abruptly here. Lamoille Valley shows greater downdrop and late Tertiary alluvial thickness than Huntington or Ruby Valleys (Satarugsa and Johnson, 2000b), and this is reflected in its greater thickness of high conductivity. A subvertical low-resistivity zone in the upper-middle crust under west-central Lamoille Valley is not well defined and data misfit is locally higher in this area. The vertical resistivity profile under the Peko Hills is more resistive than modeled for the cross line of Figure 10, where we expect sideswipe on the Peko Hills profile by conductive Lamoille Valley to the east or deep-water Paleozoic sediments to the west. We do not see evidence of thrust-related or other intense graphitization as at the west end of the other two transects even though there has been mild Sevier thrusting here and in the Adobe Range (Ketner and Alpha, 1992; Taylor et al., 2000). An extension of profiling further west would be useful for better resolution and to establish where the transition to conductive, deep-water eugeoclinal sediments begins.

The arcuate conductor under the East Humboldt Range (Figures 3 and 11) is deeper than and thus not equivalent to the low-angle East Humboldt detachment fault system of Mueller and Snoke (1993) and Snoke et al. (1997). The western surface trace of this conductor lies at the mouth of Pole Canyon (Snoke et al., 1997), the dominant topographic valley separating the East Humboldt spur from the main Ruby Mountains massif. Given that Pole Canyon progresses southward into the Ruby Valley graben, it is tempting to view this arcuate conductor as marking a listric fault accommodating divergence of the Ruby and East Humboldt Ranges here. The conductivity contrast in this interpretation is again provided by pore fluid increases and alteration including perhaps fluid mobilised graphite. From metamorphic assemblages, Peters and Wickham (1994) and McGrew et al. (2000) interpret inflow of waterrich, high-temperature fluids nearby to the north in latest Oligocene time, probably related to extension and magmatism. However, it is not necessary from the MT that there be any particular displacement on this presumably normal fault, although little offset is marked here by Snoke et al. (1997). Conceivably, this listric fault could steepen southward to merge with the vertical conductive zone flanking the eastern Ruby Mountains scarp at Harrison Pass (Figures 3 and 11), in which case a Basin-Range regime activation seems more likely. The $12 \mathrm{~km}$ long CDP line in the East Humboldt Range (Figure 1) resolved layering at depths $>12 \mathrm{~km}$ which was correlated by Stoerzel and Smithson (1998) with compositional changes rather than structural discontinuities. Some east-dipping reflectors possibly representing shear zones in the upper few kilometers under Secret Pass were imaged in CDP surveying by Valasek et al. (1989) (Figure 1) but this line does not cross the projection of Pole Canyon.

The relationship of this listric fault to the east-west trending shallow conductor imaged within the crystalline rocks (Figures 10 and 11) is unclear. The latter lies north of the approximate position of the Archean-Proterozoic transition as marked by Wright and Snoke (1993) (Figure 1) although elements of such a suture may be broadly distributed. Conducting phases could be hydrothermal alteration superimposed in a later event upon the high-grade mineralogy of the core rocks, or a graphitic zone representing an ancient horizon caught up in the suturing perhaps with fluid-induced redistribution (Boerner et al., 1996; Wannamaker, 2000). Graphite in Paleozoic protoliths (possibly Chainman Shales) now at high metamorphic grade is reported by Peters and Wickham (1994) and McGrew et al. (2000). The apparent termination of the conductor at the 
east-west lateral limits of the resistive massif in the subsurface corroborates our interpreted core complex geometry, but does not provide dating as these bounds could merely reflect a change in host rock (to Paleozoic sediments) for the causative event. A fainter zone of somewhat lower resistivity is seen dipping northward under the Cross Secret line in Figure 10, but any relation to the Proterozoic suture or other structure is unconstrained.

The resistivity of the lower crust below the Secret Pass transect appears similar to that under the Harrison Pass and Bald Mountain lines and has changed rather little from the a priori 1D profile (Figure 3). There is hence little correlation between lower crustal resistivity and degree of core complex uplift, which is interpreted to increase steadily from south to north (Hudec, 1992; Snoke et al., 1997). We believe the deep crustal resistivity is determined primarily by lowporosity hypersaline fluids and water-undersaturated melts reflecting the current, broad-scale physico-chemical state of the Great Basin interior, as discussed by Wannamaker et al. (1997b) and Wannamaker (2000). Satarugsa and Johnson (2000a) also conclude that core complex deep crust differs little from background Great Basin properties both in seismic velocity structure and Moho depth. High seismic velocities and low Poisson's ratios also imply only low fluid porosities $(<\sim 1$ vol. \%) are possible, and in fact are compatible with no porosity (Stoerzel and Smithson, 1998; Satarugsa and Johnson, 2000a).

Nevertheless, there is a weak but intriguing enhancement of conductivity (by 2) centrally located on each profile beneath the main area of uplift. While we may suppress this enhancement somewhat in alternate inversions at the expense of increasing conductivity of the subvertical crustal-scale conductors, it is hard to explain as a mere regularization artifact. In contrast, the resistive bodies towards the east and west ends of the Bald Mountain line, plus the pronounced resistor under the Pinon Range correlated with Eocene intrusion, smear slightly into the regional lower-crustal conductor increasing the resistivity locally. This is more normal behavior for smooth inversions. Although early Tertiary core complex activity may be overprinted now, McGrew et al. (2000) note that uplift persisted through the Oligocene. Also, Thorman and Brooks (1996) on the basis of stratal tilts infer much of the uplift in the northern Ruby Mountains may be post late Miocene. Thus, perhaps a unique state of stress remains below the Ruby Mountains, which may affect the degree of fluid interconnection at least in the ductile regime (Tullis et al., 1996). Mafic igneous underplate can be a direct source of lower crustal fluids in extensional regimes (Wannamaker et al., 1997a,b). Unfortunately, existing wide-angle seismic models differ greatly in the interpreted amounts of mafic material derived from the mantle (Stoerzel and Smithson, 1998; Satarugsa and Johnson, 2000a).

\section{SUMMARY AND CONCLUSIONS}

The extended, polyphase tectonism of northeast Nevada is reflected in its crustal electrical resistvity structure. The eastern reaches of our transects show the relatively undisturbed Phanerozoic shelf section is of moderate resistivity and important marker horizons for MT are the Chainman Shales and perhaps the Pioche Shale. These units appear to terminate through conductive, crustal-scale fault zones and alteration against intrusive and core complex rocks central to the transects. The crystalline rocks can be quite resistive compared to the displaced sedimentary section around them and this contrast persists to mid-crustal depths (10$20 \mathrm{~km}$ ). While some enhancement of shale conductances through tectonic graphitization is possible even in the east, large increases in conductance are observed in areas to the west that experienced overthrust deformation such as in the Diamond Range. Conductance behavior

suggests that resistivity structure can be used to map the degree of maturity of organic shales 
with location especially if shale geometries are constrained independently. Fluid-deposited graphite may be an important type of rock alteration in terms of conductivity, which is not necessarily conformable to bedding and can be associated with hydrothermal events such as Eocene magmatism in the southern Carlin Trend.

Resistive core complex rocks as seen on the Harrison Pass and Secret Pass profiles extend part way under their neighboring valleys where they appear to terminate along steep lateral boundaries into the middle crust. The outer boundaries of the deep core complex rocks and occasional zones within the core rocks are steep conductors with connection to the lower crust. These act to bleed off upper crustal electric currents induced in graben fill and other conductive sediments and could provide pathways for fluid connection between the lower and upper crust. They may have been established initially during core complex uplift but reactivation during Basin and Range extension seems likely. In particular, the conductor interpreted as a listric fault under the East Humboldt Range seems more probably to be of Basin-Range age and may connect southward to a subvertical disruption at the Harrison Pass range front. Additional MT profiling would be helpful in determining if the Ruby Mountains core complex area is unique in the degree of expression of such structures. Such steep, crustal fault zones regionally could act to preserve low effective elastic strength of the crust in the Great Basin and may exemplify those accommodating slip in the large, normal-faulting events which nucleate at mid-crustal depths.

The electrical structure of the lower crust in the region is approximately one-dimensional with low resistivities in the $20-35 \mathrm{~km}$ depth range. It shows little relation to degree of core complex uplift northward and is believed to be dominated by the late Tertiary, broad-scale extension of the Great Basin. This is in accord with some wide-angle velocity models. The low resistivities can be explained by small quantities ( $<1$ vol. \%) of hypersaline brines (upper levels) or possible water-undersaturated crustal melts (lower levels). We infer that such fluids are mostly residual to peak extensional activity 10-15 Ma. The lower bound to this conductor may lie near the seismic/compositional Moho and mark a transition in fluid/melt composition and interconnection from feldspar-dominated crustal rocks to olivine-dominated mantle mineralogy. However, there is weak evidence for a central conductive N-S axis under the Ruby Mountains including the Bald Mountain area possibly related to deep stresses local to the core complex.

Resistivity structures of the southern extension of the Carlin mineral trend into the Pinon Range include a uniformly resistive region expanding with depth to the lower crust, which is interpreted as an Eocene intrusive complex. Steep conductors flank this body and may represent deformed and graphitized organic horizons or fluid remobilized graphite and alteration. Nevertheless, it is unclear whether such resistivity expression would be unique to the mineral trend or could exist off-trend in other intrusive areas. The southern Carlin trend lies in a rather abrupt transition between miogeoclinal platform stratigraphy to the east and former deep-water, eugeoclinal clastic rocks to the west, the latter of which appear thick and conductive under Pine Valley and westward. It is suggested that the overlap of intense Eocene magmatism of the Northeast Nevada Volcanic Field with thick sections of deep water sediments along a major ancient crustal break provided the heat, the source rocks and perhaps the deep permeability for mobilizing gold-bearing solutions to the upper crust for mineral deposition. 


\section{ACKNOWLEDGEMENT}

Data collection and preliminary interpretation in this project were supported by U.S. National Science Foundation grant EAR95-96068 (Continental Dynamics). U.S. Department of Energy contracts DE-AC07-90ID12929 and 95ID13274 and NSF grant EAR96-16450 (EMSOC facility) funded design and construction of the MT instrumentation, under direction of John Stodt. Cross-line data collection, final inversion and synthesis were supported by the U.S. Geological Survey under contract 98CRGR1003. Zonge Engineering and Research Organization generously donated eight MT sites at the west end of the Harrison Pass profile. We are grateful for access to survey sites by the Bureau of Land Management, the Humboldt National Forest Service, Placer Dome Mining Corp., and numerous private land owners, especially Mr. Von Sorenson and family. Able field support was given by Alex Boynton, John Hockhalter, Patricia Lugao, John Stodt, and Michelle Thompson. Very helpful reviews were given by Keith Howard, V. J. S. Grauch and Elizabeth J. Crafford. Tim Sodergren carried out calculations and plots for the geoelectric strike estimates and Doug Jensen prepared some of the illustrations. 


\section{REFERENCES}

Armstrong, R. L., 1968, Sevier orogenic belt in Nevada and Utah: Geol. Soc. Amer. Bull. 78, 429-458.

Armstrong, R. L., 1982, Cordilleran metamorphic core complexes: Ann. Rev. Earth Planet. Sci. 10, 129154.

Axen, G. J., Taylor, W. J., and Bartley, J. M., 1993, Space-time patterns and tectonic controls of Tertiary extension and magmatism in the Great Basin of the western United States: Geol. Soc. Amer. Bull. 105, 56-76.

Axen, G. J., Selverstone, J., Byrne, T., and Fletcher, J. M., 1998, If the strong crust leads, will the weak crust follow?: GSA Today 8, 1-8.

Bahr, K., 1988, Interpretation of the magnetotelluric impedance tensor: regional induction and local telluric distortion: J. Geophys. 62, 119-127.

Barnes, C. G., Burton, B. R., Burling, T. C., Wright, J. E., and Karlsson, H. R., 2001, Petrology and geochemistry of the Late Eocene Harrison Pass pluton, Ruby Mountains core complex, northeastern Nevada: J. Petrol. 42, 901-929.

Berdichevsky, M. N., Dmitriev, V. I., and Pozdnjakova, E. E., 1998, On two-dimensional interpretation of magnetotelluric soundings: Geophys. J. Int. 133, 585-606.

Boerner, D. E., Kurtz, R. D., and Craven, J. A., 1996, Electrical conductivity and Paleo-Proterozoic foredeeps: J. Geophys. Res. 101, 13,775-13,791.

Brooks, W. E., Thorman, C. H., and Snee, L. W., 1994, Eocene volcanism in northest Nevada and adjacent Utah: in Thorman, C. H., Nutt, C. J., and Potter, C. J. (Eds.), Dating of Pre-Tertiary attenuation structures in Upper Paleozoic and Mesozoic rocks and the Eocene history in northeast Nevada and northwest Utah, Nevada Petr. Soc., Reno, 13-20.

Brooks, W. E., Thorman, C. H., and Snee, L. W., 1995, The ${ }^{40} \mathrm{Ar} /{ }^{39} \mathrm{Ar}$ ages and tectonic setting of the middle Eocene northeast Nevada volcanic field: J. Geophys. Res. 100, 10,403-10,416.

Burchfiel, B. C., Cowan, D. S., and Davis, G. A., 1992, Tectonic overview of the Cordilleran orogen in the western United States, in Burchfiel, B. C., Lipman, P. W., and Zoback, M. L. (Eds.), The Cordilleran orogen: conterminous U. S.: The Geology of North America G-3, Geol. Soc. Amer., Boulder, CO, 407480.

Carmichael, I. S. E., 1991, The redox states of basic and silicic magmas: a reflection of their source regions?: Contr. Mineral. Petr. 106, 129-141.

Carpenter, D. G., Carpenter, J. A., Dobbs, S. W., and Stewart, S. A., 1993a, Regional structural synthesis of the Eureka fold-and-thrust belt, east-central Nevada: in Gillespie, C. W. (Ed.), Structural and stratigraphic relationships of Devonian reservoir rocks, east-central Nevada, Nevada Petr. Soc., Reno, 59-72.

Carpenter, D. G., Carpenter J. A., and, Dobbs, S. W., 1993b, Fault reactivation and deactivation in the Basin-Range, western United States: in Gillespie, C. W. (Ed.), Structural and stratigraphic relationships of Devonian reservoir rocks, east-central Nevada, Nevada Petroleum Society, Reno, NV, 73-87.

Carpenter, D. G., Carpenter J. A., and, Dobbs, S. W., 1993c, Structural analysis of the Pine Valley, Nevada: in Gillespie, C. W. (Ed.), Structural and stratigraphic relationships of Devonian reservoir rocks, east-central Nevada, Nevada Petr. Soc., Reno, 9-49.

Carpenter, D. G., Carpenter, J. A., and Dobbs, S. W., 1994, Antler orogeny: paleostructural analysis and constraints on plate tectonic models with a global analogue in southeast Asia, in Dobbs, S. W., and Taylor, W. J. (Eds.), Structural and stratigraphic investigations and petroleum potential of Nevada, with special emphasis south of the Railroad Valley producing trend, vol. II, Nevada Petr. Soc., Reno, 187240.

Christiansen, R. L., and Yeats, R. S., 1992, Post-Laramide geology of the U. S. Cordilleran region, in Burchfiel, B. C., Lipman, P. W., and Zoback, M. L., (Eds.), The Cordilleran orogen: conterminous U. S.: The Geology of North America G-3, Geol. Soc. Amer., Boulder, CO, 261-406.

Christiansen, E. H., Sheridan, M. F., and Burt, D. M., 1986, The geology and geochemistry of Cenozoic topaz rhyolites from the western United States: Geol. Soc. Amer. Spec. Pap. 205, 82 p. 
Coats, R. R., 1987, Geology of Elko County, Nevada, Nev. Bur. Mines Geol., Bull. 101, 1 plate, 112 pp.

Crafford, A. E. J., and Grauch, V. J. S., 2002. Geologic and geophysical evidence for the influence of deep crustal structures on Paleozoic tectonics and the alignment of world-class gold deposits, north-central Nevada, USA. Ore Geol. Rev., this issue.

Davis, D. A., and Tingley, J. V., 1999, Gold and silver resources in Nevada: Map. 120, Nev. Bur. Mines Geol., Reno.

DeLugao, P. P., and Wannamaker, P. E., 1996, Calculating the two-dimensional magnetotelluric Jacobian in finite elements using reciprocity: Geophys. J. Int. 127, 806-810.

Dickenson, W. R., 2001. Tectonic setting of the Freat Basin through geologic time: potential implications for metallogeny. In. Shaddrick, D. R., Zbinden, E., Mathewson, D. C., and Prenn, C., (Eds.), Regional Tectonics and Structural Control of Ore: The Major Gold Trends of Northern Nevada, Spec. Publ. 33. Geol. Soc. Nev., Reno, 115-128.

Dobbs, S. W., Carpenter, J. A., and Carpenter, S. W., Dobbs, 1993, Structural analysis from the Roberts Mountains to the Diamond Mountains, Nevada: estimates on the magnitude of contraction and extension: in, Gillespie, C. W. (Ed.), Structural and stratigraphic relationships of Devonian reservoir rocks, east-central Nevada, Nevada Petr. Soc., Reno, 51-58.

Dobbs, S. W., Garbee, J. J., Jr., Stuart, C. K., and Nelson, S. L., 1994, Integrated geological and geophysical interpretation in the Newark Valley area, Eureka fold-and -thrust belt, east-central Nevada: in Dobbs, S. W., and Taylor, W. J. (Eds.), Structural and stratigraphic investigations and petroleum potential of Nevada, with special emphasis south of the Railroad Valley producing trend, vol. II, Nevada Petroleum Society, Reno, 241-253.

Doerner, W. M., 1996, Crustal structure and physical state of the Diamond Mountains-Southern Ruby Mountains-Butte Mountains District, east-central Nevada, implied using the magnetotelluric method, M. S. thesis, University of Utah, 59 pp.

Dosso, H. W., and Meng, Z. M., 1992, The coast effect response in geomagnetic field measurements: Phys. Earth Planet. Int. 70, 39-56.

Duba, A., and Constable, S., 1993, The electrical conductivity of lherzolite: J. Geophysical Res. 98, $11,885-11,899$.

Elison, M. W., 1996, Causes and consequences of Jurassic magmatism in the northern Great Basin: implications for tectonic development: in, Miller, D. M., and Busby, C. (Eds.), Jurassic magmatism and tectonics of the North American cordillera, Geol. Soc. Amer. Spec. Paper 299, 249-266.

Fink, R. A., and van de Kamp, P. C., 1992, Summary of the SOHIO, \#1 Ruby Valley Federal, Elko County, Nevada, in Trexler, J. H., Jr., Flanigan, T. E., Flanigan, D. M. H., Hansen, M. W., and Garside, L. (Eds.), Structural geology and petroleum potential of southwest Elko County, Nevada, Fieldtrip Guidebook, Nevada Petr. Soc., Reno, 86-87.

Foster, N. H., and Vincelette, R. R., 1991, Petroleum potential of the Great Basin, in Gluskoter, H. J., Rice, D. D., and Taylor, R. B. (Eds.), Economic Geology, U. S., The Geology of North America, P-2, Geol. Soc. Amer., Boulder, CO, 403-416.

Frost, B. R., and Bucher, K., 1994, Is water responsible for geophysical anomalies in the deep continental crust? A petrological perspective: Tectonophys. 231, 293-309.

Gamble, T., Goubau, W., and Clarke, J., 1979, Magnetotellurics with a remote reference: Geophys. 44, 53-68.

Giles, K. A., and Dickinson, W. R., 1995, The interplay of eustasy and lithospheric flexure in forming stratigraphic sequences in foreland settings: an example from the Antler foreland, Nevada and Utah: in Stratigraphic evolution of foreland basins, SEPM Spec. Publ. 52, 187-211.

Grauch, V. J. S., 1996, Magnetically interpreted, granitoid plutonic bodies: in Singer, D. A., (Ed.), An analysis of Nevada's metal-bearing mineral resources, Nev. Bur. Mines Geol. OF Rept. 96-2, 7-1 - 716.

Grauch, V. J. S., Jachens, R. C., and Blakely, R. J., 1995, Evidence for a basement feature related to the Cortez disseminated gold trend and implications for regional exploration in Nevada: Econ. Geol. 90, 203-207. 
Groom, R. W., and Bailey, R. C., 1989, Decomposition of magnetotelluric impedance tensor in the presence of local three-dimensional galvanic distortion: J. Geophys. Res. 94, 1913-1925.

Grunder, A. L., 1995, Material and thermal roles of basalt in crustal magmatism: case study from eastern Nevada: Geol. 23, 952-956.

Haak, V., and Hutton, R., 1986, Electrical resistivity in continental lower crust: in Dawson, J. B., D. A. Carswell, J. Hall, and K. D. Wedepohl (Eds.), Nature of Lower Continental Crust, Geol. Soc. Spec. Publ. London, 24, 35-49.

Hansen, J. B., Ransom, K. L., and Schaftenaar, C. H., 1994, North Willow Creek oil field, Eureka County, Nevada: in Schalla, R. A. and Johnson, E. H. (Eds.), Oil Fields of the Great Basin, Nevada Petr. Soc., Reno, 327-332.

Harry, D. L., and Leeman, W. P., 1995, Partial melting of melt metasomatized subcontinental mantle and the magma source potential of the lower lithosphere: J. Geophys. Res. 100, 10,255-10,269.

Harry, D. L., Sawyer, D. S., and Leeman, W. P., 1993, The mechanics of continental extension in western North America: implications for the magmatic and structural evolution of the Great Basin ; Earth Planet. Sci. Lett., v. 117, p. 59-71.

Hauser, E., Potter, C., Hauge, T., Burgess, S., Burtch, S., Mutschler, J., Allmendinger, J., Brown, L., Kaufman, S., and Oliver, J., 1987, Crustal structure of eastern Nevada from COCORP deep seismic reflection data: Geol. Soc. Amer. Bull. 99, 833-844.

Hazlett, D. P., Bregar, J. E., and Hersch, J. B., 1992, Petroleum potential of southern Huntington Valley and results of the Anadarko Cherry Spring Federal 30-44, White Pine County, Nevada: in, Trexler, J. H., Jr., Flanigan, T. E., Flanigan, D. M. H., Hansen, M. W., and Garside, L. (Eds.), Structural geology and petroleum potential of southwest Elko County, Nevada, Nevada Petr. Soc., Reno, 61-70.

Henry, C. D., and Ressel, M. W., 2000, Eocene magmatism of northeastern Nevada: the smoking gun for Carlin-type gold deposits: in Cluer, J. K., Price, J. G., Struhsacker, E. M., Hardyman, R. F., and Morris, C. L. (Eds.), Geology and ore deposits 2000: the Great Basin and beyond, Geol. Soc. Nev., Reno, 365388.

Hildenbrand, T. G., Berger, B., Jachens, R. C., and Ludington, S., 2000, Regional crustal structures and their relationship to the distribution of ore deposits in the western United States, based on magnetic and gravity data: Econ. Geol. 95, 1583-1603.

Holness, M. B., 1996, Surface chemical controls on pore-fluid connectivity in texturally equilibrated materials, in Jamveit, B., and Yardley, B. (Eds.), Fluid flow and transport in rocks, Chapman \& Hall, London, 149-169.

Holness, M. B., 1997, The permeability of non-deforming rock, in Holness, M. B. (Ed.), Deformation-enhanced fluid transport in the Earth's crust and mantle, Chapman \& Hall, London, 939.

Howard, K. A., 1992, Ruby Mountains metamorphic core complex: deep crustal exposures exhumed from beneath the Pinon Range, in Trexler, J. H., Jr., Flanigan, T. E., Flanigan, D. M. H., Hansen, M. W., and Garside, L. (Eds.), Structural geology and petroleum potential of southwest Elko County, Nevada, Nevada Petr. Soc., Reno, 57-60.

Hudec, M. R., 1992, Mesozoic structural and metamorphic history of the central Ruby Mountains metamorphic core complex, Nevada: Geol. Soc. Amer. Bull. 104, 1086-1100.

Ilchik, R. P., and Barton, M. D., 1997, An amagmatic origin of Carlin-type gold deposits: Econ. Geol. 92, 269-288.

Inan, S., 1993, The thermal maturity and petroleum potential of the Mississippian Chainman Formation: implications for the burial and thermal histories of east-central Nevada: Ph.D. thesis, Pennsylvania State Univ., 306 pp.

Inan, S., and Davis, A., 1994, The history of oil generation in Pine and Railroad Valleys, eastern Nevada: in Schalla, R. A. and E. H. Johnson (Eds.), Oil Fields of the Great Basin, Nevada Petr. Soc., Reno, 5784.

Iverson, B. G., 1992, Stratigraphy of the northern Pinon Range, southwestern Elko County, Nevada, in, Trexler, J. H., Jr., Flanigan, T. E., Flanigan, D. M. H., Hansen, M. W., and Garside, L. (Eds.), Structural 
geology and petroleum potential of southwest Elko County, Nevada, Fieldtrip Guidebook, Nevada Petr. Soc., Reno, 51-56.

Jiracek, G.R., Haak, V., and Olsen, K.H., 1995, Practical magnetotellurics in a continental rift environment, in Olsen, K.H. (Ed.), Continental Rifts: Evolution, Structure and Tectonics, Elsevier, New York, 103-129.

Jones, A. G., 1992, Electrical conductivity of the continental lower crust, in Fountain, D. M., Arculus, R. J., and Kay, R. W. (Eds.), Continental lower crust, Elsevier, 81-143.

Karlstrom, K. E., Ahall, K.-I., Harlan, S. S., Williams, M. L., McLelland, J., and Geissman, J. W., 2001, Long-lived (1.8-1.0 Ga) convergent orogen in southern Laurentia, its extensions to Australia and Baltica, and implications for refining Rodinia: Precamb. Res. 111, 5-30.

Kerrich, R. , 1999, Nature's gold factory: Science 284, 2101-2102.

Ketner, K. B., and Alpha, A. G., 1992, Mesozoic and Tertiary rocks near Elko, Nevada - evidence for Jurassic to Eocene folding and low-angle faulting: U. S. Geol. Surv. Bull. 1988-C, 13 pp.

Kuehn, C. A., and Rose, A. W., 1995, Carlin gold deposits, Nevada: origin in a deep zone of mixing between normally pressured and overpressured fluids: Econ. Geol. 90, 17-36.

Lowry, A. R., Ribe, N. M., and Smith, R. B., 2000, Dynamic elevation of the Cordillera, western United States, J. Geophys. Res., 105, 23,371-23,390.

Luque, F. J., Pasteris, J. D., Wopenka, B., Rodas, M., and Barrenechea, J. F., 1998, Natural fluiddeposited graphite: mineralogical characteristics and mechanisms of formation: Amer. J. Sci., 298, 471-498.

Lush, A. P., McGrew, A. J., Snoke, A. W., and Wright, J. E., 1988, Allochthonous Archean basement in the northern East Humboldt Range, Nevada: Geol. 16, 349-353.

MacCready, T., Snoke, A. W., Wright, J. E., and Howard, K. A., 1997, Mid-crustal flow during Tertiary extension in the Ruby Mountains core complex, Nevada: Geol. Soc. Amer. Bull. 109, 1576-1594.

Mackie, R. L., Bennett, L., and Madden, T. R. , 1988, Long period magnetotelluric measurements near the central California coast: a land-locked view of the conductivity structure under the Pacific Ocean: Geophys. J. Int. 95, 181-194.

McGrew, A. J., Peters, M. T., and Wright, J. E., 2000, Thermobarometric constraints on the tectonothermal evolution of the East Humboldt Range metamorphic core complex, Nevada: Geol. Soc. Amer. Bull. $112,45-60$.

Mueller, K. J., and Snoke, A. W., 1993, Progressive overprinting of normal fault systems and their role in Tertiary exhumation of the East Humboldt-Wood Hills metamorphic complex, northeast Nevada: Tectonics 12, 361-371.

Newman, G. W., and Witter, G. G., 1992, The Silurian-Devonian shelf-margin, a Late Paleozoic outershelf arch, and unique preservation of pre-Tertiary structures northwest of Elko, Nevada, in Trexler, J. H., Jr., Flanigan, T. E., Flanigan, D. M. H., Hansen, M. W., and Garside, L. (Eds.), Structural geology and petroleum potential of southwest Elko County, Nevada, Fieldtrip Guidebook, Nevada Petr. Soc., 424.

Nutt, C. J., Hofstra, A. H., Hart, K. S., and Mortensen, J. K., 2000, Structural setting and genesis of gold deposits in the Bald Mountain-Alligator Ridge area, east-central Nevada:in Cluer, J. K., Price, J. G., Struhsacker, E. M., Hardyman, R. F., and Morris C. L. (Eds.), Geology and ore deposits 2000: the Great Basin and beyond, Geol. Soc. Nev., Reno, 513-537.

Ostrander, A., 1990, Structural mapping at the Tomera Ranch oil field using CSAMT: a case history: in Flanigan, D. M. H., Garside, L. J., and Hansen, M. (Eds.), Oil fields and geology of the Pine Valley, Eureka County area, Nevada, Nev. Petr. Soc. Fieldtr. Guidb., 57-68.

Park, S. K., Biasi, G. P., Mackie, R. L., and Madden, T. R., 1991, Magnetotelluric evidence of crustal suture zones bounding the southern Great Valley, California: J. Geophys. Res. 96, 353-376.

Park, S. K., Hirasuna, B., Jiracek, G. R., and Kinn, C., 1996, Magnetotelluric evidence of lithospheric mantle thinning beneath the southern Sierra Nevada: J. Geophys. Res. 101, 16,241-16,255.

Parker, R. L., and Booker, J. R., 1996, Optimal one-dimensional inversion and bounding of magnetotelluric apparent resistivity and phase measurements: Phys. Earth Planet. Inter. 98, 269-282. 
Parkinson, I. J., and Arculus, R. J., 1999, The redox state of subduction zones: insights from arcperidotites: Chem. Geol. 160, 409-423.

Pasteris, J. D. , 1999, Causes of the uniformly high crystallinity of graphite in large epigenetic deposits: J. Struct. Geol. 17, 779-787.

Perry, A. J., 1995, Depositional setting of the Upper Mississippian to Lower Pennsylvanian Newark Valley sequence, Diamond Range, Nevada: in Hansen, M. W., Walker, J. P., and Trexler, J. H., Jr. (Eds.), Mississippian source rocks in the Antler Basin of Nevada and associated structural and stratigraphic traps, Nevada Petr. Soc., Reno, 97-113.

Perry, F. V., DePaolo, D. J., and Baldridge, W. S, 1993, Neodymium isotopic evidence for decreasing crustal contributions to Cenozoic ignimbrites of the western United States: implications for the thermal evolution of the Cordilleran crust: Geol. Soc. Amer. Bull. 105, 872-882.

Peters, M. T., and Wickham, S. M., 1994, Petrology of upper amphibolite facies marbles from the East Humboldt Range, Nevada, USA; evidence for high-temperature, retrograde, hydrous volatile fluxes at mid-crustal levels: J. Petrol. 35, 205-238.

Phillips, G. N., and Powell, R., 1993, Link between gold provinces: Econ. Geol., 88, 1084-1098.

Ponce, D. A., 1992, Bouguer gravity map of Nevada, Ely sheet, Nevada Bur. Mines Geol., Map 99, 1 sheet.

Ponce, D. A., Morin, R. L., and Robbins, S. L., 1996, Bouguer gravity map of Nevada, Elko sheet, Nevada Bur. Mines Geol., Map 107, 1 sheet.

Poole, F. G., Stewart, J. H., Palmer, A. R., Sandberg, C. A., Madrid, R. J., Ross, R. J., Jr., Hintze, L. F., Miller, M. M., and Wrucke, C. T., 1992, Latest Precambrian to latest Devonian time; development of a continental margin, in Burchfiel, B. C., Lipman, P. W., and Zoback, M. L. (Eds.), The Cordilleran orogen: conterminous U. S.: The Geology of North America G-3, Geol. Soc. Amer., Boulder, CO, 9-56.

Potter, C., Liu, C. S., Huang, J., Zheng, L., Hague, T., Hauser, E., Allmendinger, R., Oliver, J. E., Kaufman, S., and Brown, L., 1986, Crustal structure of north-central Nevada: results from COCORP deep seismic profiling: Geol. Soc. Amer. Bull. 98, 330-337.

Ransom, K. L., and Hansen, J. B., 1993, Cretaceous transpressional deformation, Eureka County, Nevada: in Gillespie, C. W. (Ed.), Structural and stratigraphic relationships of Devonian reservoir rocks, eastcentral Nevada, Nevada Petr. Soc., Reno, NV, 89-104.

Reese, N. M., 1986, Cenozoic tectonic history of the Ruby Mountains and adjacent areas, northeastern Nevada: constraints from radiometric dating and seismic reflection profiles: M. S. thesis, Southern Methodist Univ., $88 \mathrm{pp}$.

Rigby, J. K., 1960, Geology of the Buck Mountain-Bald Mountain area, southern Ruby Mountains, White Pine County, Nevada: in Guidebook to the geology of east-central Nevada, Interm. Assoc. Petr. Geol. and East. Nev. Geol. Soc., 11th Ann. field conf., 173-180.

Rodi, W. L., and Mackie, R. L., 2001, Nonlinear conjugate gradients algorithm for 2-D magnetotelluric inversion: Geophys. 66, 174-187.

Rodriguez, B. D., and Williams, J. M., 2001, Deep regional resistivity structure across the Battle Mountain-Eureka and Carlin trends, north-central Nevada: U. S. Geol. Surv. Open File Rep. 01-346, $165 \mathrm{pp}$.

Rodriguez, B. D., and Williams, J. M., 2002, Resistivity structure across the Humboldt River Basin, northcentral Nevada: U. S. Geol. Surv. Open File Rep. 02-39, 114 pp.

Sadlick, W., 1995, Stratigraphic subdivision of the Chainman Formation, in Hansen, M. W., Walker, J. P., and Trexler, J. H., Jr. (Eds.), Mississippian source rocks in the Antler Basin of Nevada and associated structural and stratigraphic traps, Nevada Petr. Soc., Reno, 3-44.

Satarugsa, P., and Johnson, R. A., 1998, Crustal velocity structure beneath the eastern flank of the Ruby Mountains metamorphic core complex: results from normal-incidence to wide-angle seismic data: Tectonophys. 295, 369-395.

Satarugsa, P., and Johnson, R. A., 2000a, Constraints on crustal composition beneath a metamorphic core complex: results from 3-component wide-angle seismic data along the eastern flank of the Ruby Mountains, Nevada: Tectonophys. 329, 223-250. 
Satarugsa, P., and Johnson, R. A., 2000b, Cenozoic tectonic evolution of the Ruby Mountains metamorphic core complex and adjacent valleys, northeastern Nevada: Rocky Mt. Geol. 35, 205-230.

Saucier, A. E., 1997, The Antler thrust system in northern Nevada, in Perry, A. J., and Abbott, E. W. (Eds.), The Roberts Mountains thrust, Elko and Eureka Counties, Nevada, Nevada Petr. Soc., Reno, 116.

Schalla, R. A., 1992, Results of exploratory drilling in Huntington Valley near Jiggs, Elko County, Nevada, in Trexler, J. H., Jr., Flanigan, T. E., Flanigan, D. M. H., Hansen, M. W., and Garside, L. (Eds.), Structural geology and petroleum potential of southwest Elko County, Nevada, Fieldtrip Guidebook, Nevada Petr. Soc., 71-85.

Shankland, T. J., Duba, A. G., Mathez, E. A., and Peach, C. L., 1997, Increase of electrical conductivity with pressure as an indicator of conduction through a solid phase in midcrustal rocks: J. Geophys. Res. 102, 14,741-14,750.

Silberling, N. J., Nichols, K. M., Trexler, J. H., Jr., Jewell, P. W., and Crosbie, R. A., 1997, Overview of Mississippian depositional and paleotectonic history of the Antler foreland, eastern Nevada and western Utah. In. Link, P. K., and Kowalis, B. J. (Eds.), Geol. Soc. Amer. Field Trip Guideb., BYU Geol. Stud., 42(1), 161-196.

Smith, J. F., Jr., and Ketner, K. B., 1976, Stratigraphy of post-Paleozoic rocks and summary or resources in the Carlin-Pinon Range area, Nevada: U. S. Geol. Surv. Prof. Pap. 867-B, 48 pp.

Smith, D. L., Gans, P. B., and Miller, E. L., 1991, Palinspastic restoration of Cenozoic extension in the central and eastern Basin and Range province at latitude $39-40^{\circ} \mathrm{N}$ : in Raines, G. L., Schafer, R. W., and Wilkinson, W. H. (Eds.), Geology and ore deposits of the Great Basin, Geol. Soc. Nevada, Reno, 75-86.

Smith, R. B., Nagy, W. C., Julander, K. A. S., Viveiros, J. J., Barker, C. A., and Gants, D. J., 1989, Geophysical and tectonic framework of the eastern Basin and Range-Colorado Plateau-Rocky Mountain transition, in Pakiser, L. C., and Mooney, W. D. (Eds.), Geophysical framework of the continental United States, Geol. Soc. Amer. Mem. 172, 205-233.

Smith, R. B., Meertens, C., Chang, W., Waite, G., Puskas, C. and Lowry, A., 2001, What's moving the Basin-Range? Hotspots, earthquakes and lithosphere: in Klemperer, S., and Ernst, G. (Eds.), The lithosphere of western North America, and its geophysical characterization, Proc. George Thompson Symp., Dec. 8-9, Stanford University, Stanford, CA, 12.

Snoke, A. N., McGrew, A. J., Valesek, P. A., and Smithson, S. B., 1990, A crustal cross-section for a terrain of superimposed shortening and extension: Ruby Mountains-East Humboldt Range metamorphic core complex, Nevada, in Salisbury, M. H., and Fountain, D. M. (Eds.), Exposed cross-sections of the continental crust, Kluwer, Dordrecht, 103-135.

Snoke, A. N., Howard, K. A., McGrew, A. J., Burton, B. R., Lee, S.-Y., Barnes, C. G., Burling T., Peters, M. T., and Wright, J. E., 1997, The grand tour of the Ruby-East Humboldt metamorphic core complex, northeastern Nevada: part 1 - introduction \& road log: in Link, P. K., and Kowallis, B. J. (Eds.), Proterozoic to Recent stratigraphy, tectonics, and volcanology, Utah, Nevada, southern Idaho and central Mexico: Brigham Young Univ. Geol. Stud. 42, pt. 1, 225-296.

Snyder, W. S., Spinosa, C., and Gallegos, D. M., 1991, Pennsylvanian-Permian tectonism along the western U. S. continental margin: recognition of a new tectonic event, in Raines, G. L., Schafer, R. W., and Wilkinson, W. H. (Eds.), Geology and ore deposits of the Great Basin, Geol. Soc. Nevada, Reno, 519.

Snyder, W. S., Schwarz, D. L., Spinosa, C., and Torrealday, H., 1995, Pennsylvanian-Permian tectonic sequence stratigraphy: implications for the structure and stratigraphy of eastern Nevada, in Hansen, M. W., Walker, J. P., and Trexler, J. H., Jr. (Eds.), Mississippian source rocks in the Antler Basin of Nevada and associated structural and stratigraphic traps, Nevada Petr. Soc., Reno, 125-134.

Solomon, B. J., 1992, The Elko Formation of Eocene and Oligocene (?) age - source rocks and petroleum potential in Elko County, Nevada:in Trexler, J. H., Jr., Flanigan, T. E., Flanigan, D. M. H., Hansen, M. W., and Garside, L. (Eds.), Structural geology and petroleum potential of southwest Elko County, Nevada, Fieldtrip Guidebook, Nevada Petr. Soc., 25-38.

Stewart, J. H., 1980, Geology of Nevada, Nevada Bur. Mines Geol., Spec. Publ. 4, 136 p. 
Stewart, J. H., and Carlson, J. E., 1978, Geologic map of Nevada: U. S. Geol. Surv., 1:500,000.

Stodt, J. A., 1983, Processing of conventional and remote reference magnetotelluric data: Ph. D. thesis, University of Utah, $223 \mathrm{pp}$.

Stoerzel, A., and Smithson, S. B., 1998, Two-dimensional travel-time inversion for the crustal P and S wave velocity structure of the Ruby Mountains metamorphic core complex, NE Nevada: J. Geophys. Res. 102, 21,121-21,144.

Sutarno, D., and Vozoff, K., 1989, Robust M-estimation of magnetotelluric impedance tensors: Explor. Geophys. 20, 383-398.

Tarantola, A., 1987, Inverse problem theory: Elsevier, New York, 613 pp.

Taylor, W. J., Bartley, J. M., Martin, M. W., Geissman, J. W., Walker, J. D., Armstrong, P. A., and. Fryxell, J. E, 2000, Relations between hinterland and foreland shortening: Sevier orogeny, central North American Cordillera: Tectonics 19, 1124-1143.

Teal, L., and Jackson, M., 1997, Geologic overview of the Carlin trend gold deposits: Soc. Econ. Geol. Newsl. no. 31, 12-25.

Thorman, C. H., and Brooks, W. E., 1996, Two phases of Tertiary deformation in northeastern Nevada: in Taylor, W. J., and H. Langrock (Eds.), Cenozoic structure and stratigraphy of central Nevada, Nevada Petr. Soc., Reno, 33-38.

Thorman, C. H., Ketner, K. R., Brooks, W. E., Snee, L. W., and Zimmerman, R. A., 1991, Late MesozoicCenozoic tectonics in northeastern Nevada: in Raines, G. L., Schafer, R. W., and Wilkinson, W. H. (Eds.), Geology and ore deposits of the Great Basin, Geol. Soc. Nevada, Reno, 25-47.

Thorman, C. H., Ketner, K. R., Brooks, W. E., and Peterson, F., 1992, The Elko orogeny in northeastern Nevada: in Trexler, J. H., Jr., Flanigan, T. E., Flanigan, D. M. H., Hansen, M. W., and Garside, L. (Eds.), Structural geology and petroleum potential of southwest Elko County, Nevada, Fieldtrip Guidebook, Nevada Petr. Soc., Reno, 1-4.

Torres-Verdin, C., and Bostick, F. X., Jr., 1992, Principles of spatial surface electric field filtering in magnetotellurics: electro-magnetic array profiling (EMAP): Geophys. 57, 603-622.

Tosdal, R. M., Wooden, J. L., and Kistler, R. W., 2000, Geometry of the Neoproterozoic continental breakup, and implications for location of Nevadan mineral belts: in Cluer, J. K., J. G. Price, E. M. Struhsacker, R. F. Hardyman, and C. L. Morris (Eds.), Geology and ore deposits 2000: the Great Basin and beyond, Geol. Soc. Nev., Reno, 451-466.

Trexler, J. H., and Nitchman, S. P., 1990, Sequence stratigraphy and evolution of the Antler foreland basin, east-central Nevada: Geol. 18, 422-425.

Trexler, J. H., Snyder, W. S., Cashman, P. H., Gallegos, D. M., and Spinosa, C., 1991, Mississippian through Permian orogenesis in eastern Nevada:post-Antler, pre-Sonoma tectonics of the western Cordillera, in Cooper, J. D., and Stevens, C. H. (Eds.), Paleozoic Paleogeography of the western United States - II, Pacific Section SEPM, Tulsa, 317-330.

Trexler, J. H., Snyder, W., Schwarz, D., Kurka, M. T., and Crosbie, R., 1995, An overview of the Mississippian Chainman shale, in Hansen, M. W., Walker, J. P., and Trexler, J. H., Jr. (Eds.), Mississippian source rocks in the Antler Basin of Nevada and associated structural and stratigraphic traps, Nevada Petr. Soc., Reno, 45-60.

Tullis, J., Yund, R. A., and Farver, J., 1996, Deformation-enhanced fluid distribution in feldspar aggregates and implications for ductile shear zones: Geol. 24, 63-66.

Valasek, P. A., Snoke, A. W., Hurich, C. A., and Smithson, S. B., 1989, Nature and origin of seismic reflection fabric, Ruby-East Humboldt metamorphic core complex, Nevada: Tectonics 8, 391-415.

van de Kamp, P. D., and Samoun, A., 1992, Petroleum generation in the Elko Formation: in Trexler, J. H., Jr., Flanigan, T. E., Flanigan, D. M. H., Hansen, M. W., and Garside, L. (Eds.), Structural geology and petroleum potential of southwest Elko County, Nevada, Fieldtrip Guidebook, Nevada Petr. Soc., Reno, $39-50$.

Van Schmus, W. R., Bickford, M. E., Anderson, J. L., Bender, E. E., Anderson, R. R., Bauer, P. W., Robertson, J. M., Bowring, S. A., Condie, K. C., Denison, R. E., Gilbert, M. C., Grambling, J. A., Mawer, C. K., Shearer, C. K., Hinze, W. J., Karstrom, K. E., Kisvarsanyi, E. B., Lidiak, E. G., Reed, J. 
C., Jr., Sims, P. K., Tweto, O., Silver, L. T., Treves, S. B., Williams, M. L., and Wooden, J. L., 1993, Transcontinental Proterozoic provinces, in Reed, J. C., Jr., Bickford, M. E., Houston, R. S., Link, P. K., Rankin, D. W., Sims, P. K., and Van Schmus, W. R. (Eds.), Precambrian: conterminous U. S.: The Geology of North America C-2, Geol. Soc. Amer., Boulder, CO, 171-334.

Vozoff, K., 1991, The magnetotelluric method, in Nabighian, M. N. (Ed.), Electromagnetic methods in applied geophysics, 2B, Soc. Explor. Geophys., Tulsa, Okla., 641-711.

Wannamaker, P. E., 1999, Affordable magnetotellurics: interpretation in natural environments, in Oristaglio, M. and B. Spies (Eds.), Three-dimensional electromagnetics, Geophys. Devel. Ser., 7, Soc. Explor. Geophys., Tulsa, 349-374.

Wannamaker, P. E., 2000, Comment on "The petrologic case for a dry lower crust", by B. D. Yardley and J. W. Valley: J. Geophys. Res. 105, 6057-6064.

Wannamaker, P. E., and Hohmann, G. W., 1991, Electromagnetic induction studies: U. S. National Rep. to IUGG, Rev. Geophys., supplement, 405-415.

Wannamaker, P. E., Hohmann, G. W., and Ward, S. H., 1984, Magnetotelluric responses of three-dimensional bodies in layered earths: Geophysics, 49, 1517-1533.

Wannamaker, P. E., Stodt, J. A., and Rijo, L., 1987, A stable finite element solution for two-dimensional magnetotelluric modeling: Geophy. J. Roy. Astr. Soc. 88, 277-296.

Wannamaker, P. E., Wright, P. M., Zhou, Z.-X., Li, X. B., and Zhao, J.-X., 1991, Magnetotelluric transect of Long Valley Caldera: resistivity cross section, structural implications, and the limits of a two-dimensional analysis: Geophys. 56, 926-940.

Wannamaker, P. E., Johnston, J. M., Stodt, J. A., and Booker, J. R., 1997a, Anatomy of the Southern Cordilleran Hingeline, Utah and Nevada, from deep resistivity profiling: Geophys. 62, 1069-1086.

Wannamaker, P. E., Doerner, W. M., Stodt, J. A., and Johnston, J. M., 1997b, Subdued state of tectonism of the Great Basin interior relative to its eastern margin based on deep resistivity structure: Earth Planet. Sci. Lett. 150, 41-53.

Wannamaker, P. E. , Bartley, J. M., Sheehan, A. F., Jones, C. H., Lowry, A. R., Dumitru, T. A., Ehlers, T. A., Holbrook, W. S., Farmer, G. L., Unsworth, M. J., Hall, D. B., Chapman, D. S., Okaya, D. A., John, B. E., and Wolfe, J. A., 2001, Great Basin-Colorado Plateau transition in central Utah: An interface between active extension and stable interior, in Erskine, M. C., Faulds, J. E., Bartley, J. M. and Rowley, P. (Eds.), The Geological Transition: Colorado Plateau to Basin and Range, Proc. J. Hoover Mackin Symposium, Utah Geol. Assoc./Amer. Assoc. Petr. Geol. Publ. 30/GB78, Cedar City, Utah, September 20-23, 1-38.

Wannamaker, P. E., Jiracek, G. R., Stodt, J. A., Caldwell, T. G., Porter, A. D., Gonzalez, V. M., and McKnight, J. D., 2002, Fluid generation and pathways beneath an active compressional orogen, the New Zealand Southern Alps, inferred from magnetotelluric (MT) data: J. Geophys. Res., in press.

Wernicke, B., 1992, Cenozoic extensional tectonics of the U. S. Cordillera, in Burchfiel, B. C., Lipman, P. W., and Zoback, M. L. (Eds.), The Cordilleran orogen: conterminous U. S.: The Geology of North America G-3, Geol. Soc. Amer., Boulder, CO, 553-581.

Wright, J. E., and Snoke, A. W., 1993, Tertiary magmatism and mylonitization in the Ruby-East Humboldt metamorphic core complex, northeastern Nevada: $\mathrm{U}-\mathrm{Pb}$ geochronology and $\mathrm{Sr}, \mathrm{Nd}$, and $\mathrm{Pb}$ isotope geochemistry: Geol. Soc. Amer. Bull. 105, 935-952.

Wu, N., Booker, J. R., and Smith, J. T., 1993, Rapid two-dimensional inversion of COPROD2 data: J. Geomag. Geoelec. 45, 1073-1087.

Zoback, M. L., McKee, E. H., Blakely, R. J., and Thompson, G. A., 1994, The northern Nevada rift: regional tectono-magmatic relations and middle Miocene stress direction: Geol. Soc. Amer. Bull. 106, 371-382. 


\section{APPENDIX}

The following table lists the Ruby Mountains and southern Carlin trend, Nevada magnetotelluric station locations for the three regional and the two cross profiles (Figure 1). Coordinates are referenced to the 1866 Clarke spheroid and North American 1927 Western United States datum. Universal Transverse Mercator units below are in meters. Elevation is in meters.

\section{Secret Pass}

\begin{tabular}{|c|c|c|c|c|}
\hline sitename & zone & north & east & $\underline{\operatorname{elev}(\mathrm{m})}$ \\
\hline$\overline{\text { SEC 93.C25 }}$ & 11 & $4 \overline{540400}$ & $6 \overline{24600}$ & 1630 \\
\hline SEC $93 . \mathrm{C} 24$ & 11 & 4538600 & 627100 & 1670 \\
\hline SEC $93 . B 23$ & 11 & 4537600 & 628100 & 1675 \\
\hline SEC $93 . B 22$ & 11 & 4535900 & 629250 & 1620 \\
\hline SEC $93 . B 21$ & 11 & 4534350 & 632500 & 1605 \\
\hline SEC $93 . C 18$ & 11 & 4533000 & 634700 & 1635 \\
\hline SEC 93.B17 & 11 & 4531450 & 637250 & 1640 \\
\hline SEC $93 . B 16$ & 11 & 4531750 & 640000 & 1670 \\
\hline SEC $93 . B 15$ & 11 & 4530700 & 642700 & 1695 \\
\hline SEC $93 . B 14$ & 11 & 4529100 & 645400 & 1850 \\
\hline SEC $93 . C 19$ & 11 & 4527600 & 646800 & 1975 \\
\hline SEC 93.C20 & 11 & 4526700 & 647850 & 2010 \\
\hline SEC93.B03 & 11 & 4523850 & 648250 & 1970 \\
\hline SEC $93 . B 26$ & 11 & 4524300 & 649900 & 1950 \\
\hline SEC $93 . \mathrm{CO} 4$ & 11 & 4524050 & 650700 & 1960 \\
\hline SEC $93 . \mathrm{C} 28$ & 11 & 4524050 & 652200 & 2015 \\
\hline SEC 93.C01 & 11 & 4523800 & 653300 & 2020 \\
\hline SEC $93 . \mathrm{C} 29$ & 11 & 4522900 & 653900 & 1990 \\
\hline $\mathrm{SEC} 93 . \mathrm{CO} 2$ & 11 & 4522800 & 655350 & 2070 \\
\hline SEC $93 . B 30$ & 11 & 4521800 & 656450 & 2240 \\
\hline SEC $93 . B 31$ & 11 & 4521750 & 657400 & 2125 \\
\hline SEC $93 . B 32$ & 11 & 4520200 & 658350 & 2190 \\
\hline SEC $93 . \mathrm{B} 06$ & 11 & 4519650 & 659850 & 2225 \\
\hline SEC 93.C07 & 11 & 4518550 & 663000 & 2060 \\
\hline SEC93.C08 & 11 & 4517400 & 664650 & 1820 \\
\hline SEC $93 . \mathrm{C} 09$ & 11 & 4516150 & 666250 & 1740 \\
\hline SEC93.B10 & 11 & 4513900 & 667700 & 1730 \\
\hline SEC $93 . B 11$ & 11 & 4513600 & 671150 & 1720 \\
\hline SEC $93 . \mathrm{B} 12$ & 11 & 4513100 & 674650 & 1720 \\
\hline SEC $93 . B 13$ & 11 & 4512600 & 678450 & 1740 \\
\hline SEC $96 . B 33$ & 11 & 4512200 & 680900 & 1755 \\
\hline SEC $96 . B 34$ & 11 & 4512200 & 682300 & 1800 \\
\hline SEC $96 . B 35$ & 11 & 4511800 & 683400 & 1860 \\
\hline SEC $96 . B 36$ & 11 & 4511600 & 684400 & 1940 \\
\hline SEC $96 . B 37$ & 11 & 4511100 & 685400 & 1840 \\
\hline $96 . B 38$ & 11 & 4510600 & 686600 & 1790 \\
\hline 6.839 & 11 & 4510300 & 687900 & 1740 \\
\hline SEC $96 . B 40$ & 11 & 4510400 & 688800 & 1730 \\
\hline SEC $96 . B 41$ & 11 & 4510400 & 689900 & 1725 \\
\hline
\end{tabular}




\section{Harrison Pass}

\begin{tabular}{|c|c|c|c|c|}
\hline sitename & zone & north & east & elev (m) \\
\hline$\overline{\mathrm{HRSP}} 97 . \mathrm{B} 60$ & $\overline{11}$ & $4 \overline{481350}$ & $5 \overline{63960}$ & 1680 \\
\hline HRSP97.B59 & 11 & 4481420 & 565210 & 1770 \\
\hline HRSP97.B58 & 11 & 4480580 & 565700 & 1820 \\
\hline HRSP 97. B5 7 & 11 & 4480400 & 566500 & 1950 \\
\hline HRSP 97. B5 6 & 11 & 4480330 & 568250 & 1830 \\
\hline HRSP 97. B5 5 & 11 & 4479770 & 570550 & 1690 \\
\hline HRSP 97. B5 4 & 11 & 4479480 & 572290 & 1650 \\
\hline HRSP 97. B52 & 11 & 4478800 & 576800 & 1640 \\
\hline HRSP 97 . B51 & 11 & 4479300 & 578200 & 1680 \\
\hline HRSP 96. B5 0 & 11 & 4479200 & 579800 & 1780 \\
\hline HRSP 96. B4 9 & 11 & 4479800 & 580800 & 1810 \\
\hline HRSP 96. B5 1 & 11 & 4480000 & 582200 & 1950 \\
\hline HRSP 96. B 48 & 11 & 4479200 & 583100 & 1970 \\
\hline HRSP 96. B 47 & 11 & 4478600 & 584100 & 2020 \\
\hline HRSP96.B4 6 & 11 & 4476800 & 584700 & 2040 \\
\hline HRSP 96. B 45 & 11 & 4476200 & 585500 & 2120 \\
\hline HRSP $96 . \mathrm{B} 43$ & 11 & 4476100 & 586700 & 2250 \\
\hline HRSP 96. B4 4 & 11 & 4475400 & 588000 & 2370 \\
\hline HRSP 96. B 42 & 11 & 4473800 & 590100 & 2170 \\
\hline HRSP 96. B2 4 & 11 & 4472100 & 591400 & 2060 \\
\hline HRSP 96. B2 5 & 11 & 4470900 & 593100 & 1980 \\
\hline HRSP96.B23 & 11 & 4471000 & 594800 & 1920 \\
\hline HRSP 96. B2 1 & 11 & 4471300 & 596600 & 1870 \\
\hline HRSP 96. B2 2 & 11 & 4471150 & 598700 & 1820 \\
\hline HRSP96.B19 & 11 & 4469200 & 600900 & 1760 \\
\hline HRSP 96. B2 0 & 11 & 4470100 & 602700 & 1740 \\
\hline HRSP 96. B1 7 & 11 & 4467400 & 605000 & 1700 \\
\hline HRSP 96. B1 8 & 11 & 4467400 & 606900 & 1670 \\
\hline HRSP 96. B1 5 & 11 & 4467000 & 609400 & 1700 \\
\hline HRSP 96. B1 6 & 11 & 4466500 & 611200 & 1740 \\
\hline HRS P 95.B11 & 11 & 4465300 & 613100 & 1770 \\
\hline HRSP 95. B12 & 11 & 4464900 & 616600 & 1820 \\
\hline HRSP 95. B0 7 & 11 & 4465500 & 619200 & 1940 \\
\hline HRSP95.B0 8 & 11 & 4465000 & 620300 & 1970 \\
\hline HRSP 95. B0 5 & 11 & 4465300 & 622000 & 2000 \\
\hline HRSP95.B0 6 & 11 & 4465200 & 623200 & 2050 \\
\hline HRSP 95. B03 & 11 & 4464600 & 624500 & 2120 \\
\hline HRSP 95 . B0 4 & 11 & 4464200 & 626100 & 2200 \\
\hline HRSP $95 . \mathrm{B} 01$ & 11 & 4464300 & 627800 & 2110 \\
\hline HRSP $95 . \mathrm{B} 02$ & 11 & 4463800 & 629600 & 2070 \\
\hline HRSP 95. B0 9 & 11 & 4463000 & 633700 & 1830 \\
\hline HRSP 95. B1 0 & 11 & 4461800 & 635300 & 1830 \\
\hline HRSP96.B26 & 11 & 4461300 & 638100 & 1830 \\
\hline HRSP 96. B2 7 & 11 & 4461200 & 640600 & 1840 \\
\hline HRSP96.B28 & 11 & 4460900 & 642500 & 1870 \\
\hline HRSP $96 . B 29$ & 11 & 4460000 & 644000 & 1910 \\
\hline HRSP 96. B30 & 11 & 4459361 & 645725 & 1950 \\
\hline HRSP96.B31 & 11 & 4458402 & 647002 & 1980 \\
\hline HRSP 96. B32 & 11 & 4458518 & 649131 & 2010 \\
\hline HRSP96.B33 & 11 & 4458610 & 650646 & 2070 \\
\hline HRSP 96. B3 4 & 11 & 4458044 & 653077 & 2200 \\
\hline HRSP96.B35 & 11 & 4458505 & 655222 & 2440 \\
\hline HRSP96.B36 & 11 & 4460235 & 656835 & 2200 \\
\hline HRSP 96. B37 & 11 & 4460148 & 658258 & 2190 \\
\hline HRSP 96. B39 & 11 & 4460538 & & 2040 \\
\hline HRSP 96. B 40 & 11 & 4459883 & 664239 & 1930 \\
\hline HRSP96.B4 1 & 11 & 4459729 & 666033 & 1870 \\
\hline
\end{tabular}




\section{Little Bald Mountain}

\begin{tabular}{|c|c|c|c|c|}
\hline sitename & zone & north & east & $\underline{\operatorname{elev}(\mathrm{m})}$ \\
\hline LTLB 94.B01 & $\frac{11}{11}$ & 4417300 & $5 \overline{93200}$ & 1755 \\
\hline LTLB 94. B02 & 11 & 4417600 & 594600 & 1760 \\
\hline LTLB $94 . B 03$ & 11 & 4417700 & 596200 & 1770 \\
\hline LTLB 94. B0 4 & 11 & 4417600 & 597800 & 1880 \\
\hline LTLB 94.B05 & 11 & 4418000 & 598900 & 2000 \\
\hline LTLB $94 . B 06$ & 11 & 4417700 & 600100 & 2030 \\
\hline LTLB 94.B07 & 11 & 4418000 & 601000 & 2150 \\
\hline LTLB 94. B0 8 & 11 & 4417900 & 602100 & 2310 \\
\hline LTLB $94 . B 09$ & 11 & 4417800 & 603350 & 2140 \\
\hline LTLB $94 . B 10$ & 11 & 4418100 & 604300 & 2050 \\
\hline LTLB 94. B 11 & 11 & 4418200 & 606100 & 1955 \\
\hline LTLB 94. B 12 & 11 & 4418300 & 607600 & 1925 \\
\hline LTLB 94.B13 & 11 & 4418000 & 610000 & 1890 \\
\hline LTLB 94. B14 & 11 & 4418100 & 611600 & 1900 \\
\hline LTLB 95.B15 & 11 & 4417900 & 613100 & 1895 \\
\hline LTLB 95. B16 & 11 & 4417950 & 615100 & 1900 \\
\hline LTLB 95.B17 & 11 & 4418100 & 617000 & 1950 \\
\hline LTLB 95.B18 & 11 & 4418100 & 619000 & 2075 \\
\hline LTLB 95.B19 & 11 & 4418000 & 621000 & 2150 \\
\hline LTLB 95.B20 & 11 & 4417750 & 623000 & 2240 \\
\hline LTLB 95.B21 & 11 & 4417600 & 624000 & 2250 \\
\hline LTLB 95. B22 & 11 & 4417900 & 625300 & 2290 \\
\hline LTLB 95.B23 & 11 & 4418500 & 626800 & 2400 \\
\hline LTLB 95. B2 4 & 11 & 4418300 & 627600 & 2420 \\
\hline LTLB 95.B25 & 11 & 4418200 & 628500 & 2270 \\
\hline LTLB 95. B2 6 & 11 & 4418300 & 629600 & 2110 \\
\hline LTLB 95.B27 & 11 & 4418300 & 630700 & 2110 \\
\hline LTLB 95.B28 & 11 & 4417800 & 632000 & 2170 \\
\hline LTLB 95.B29 & 11 & 4418400 & 633100 & 2250 \\
\hline LTLB 95.B30 & 11 & 4418100 & 634400 & 2140 \\
\hline LTLB 95.B31 & 11 & 4417700 & 636500 & 2000 \\
\hline LTLB 95.B32 & 11 & 4417600 & 638000 & 1945 \\
\hline LTLB95.B33 & 11 & 4417500 & 639200 & 1910 \\
\hline LTLB 95. B3 4 & 11 & 4417500 & 640700 & 1890 \\
\hline LTLB 95.B35 & 11 & 4417800 & 642300 & 1875 \\
\hline LTLB 95. B36 & 11 & 4417800 & 644000 & 1870 \\
\hline LTLB 95.B37 & 11 & 4417800 & 646000 & 1900 \\
\hline LTLB 95.B38 & 11 & 4417900 & 647500 & 2040 \\
\hline LTLB 95.B39 & 11 & 4417000 & 650400 & 2150 \\
\hline LTLB 95. B40 & 11 & 4417700 & 650700 & 2100 \\
\hline LTLB 95.B41 & 11 & 4417900 & 652600 & 2040 \\
\hline LTLB & 11 & 4417400 & 654200 & 1975 \\
\hline
\end{tabular}




\section{Peko Hills}

$\begin{array}{lcccc}\text { sitename } & \text { zone } & \text { north } & \text { east } & \text { elev }(\mathrm{m}) \\ \text { PKO9912 } & 11 & 4522650 & 619500 & 1640 \\ \text { PKO9911 } & 11 & 4524975 & 621925 & 1630 \\ \text { PKO9910 } & 11 & 4528000 & 622750 & 1620 \\ \text { PKO9909 } & 11 & 4530650 & 622300 & 1590 \\ \text { PKO9908 } & 11 & 4533275 & 624250 & 1630 \\ \text { PKO9907 } & 11 & 4536700 & 624600 & 1640 \\ \text { SPL9324 } & 11 & 4538600 & 627100 & 1670 \\ \text { PKO9902 } & 11 & 4542650 & 627500 & 1760 \\ \text { PKO9901 } & 11 & 4544800 & 627350 & 1830 \\ \text { PKO9904 } & 11 & 4547000 & 627950 & 1810 \\ \text { PKO9903 } & 11 & 4548450 & 628300 & 1850 \\ \text { PKO9906 } & 11 & 4550550 & 629700 & 1960 \\ \text { PKO9905 } & 11 & 4552450 & 630775 & 1880\end{array}$

\section{Cross-Secret}

$\begin{array}{lcccc}\text { Sitename } & \text { zone } & \text { north } & \text { east } & \text { elev }(\mathrm{m}) \\ \text { CAR9914 } & \text { 11 } & 4 \text { 519550 } & 649125 & 2150 \\ \text { CAR9913 } & 11 & 4520350 & 650700 & 2050 \\ \text { CAR9916 } & 11 & 4521175 & 652050 & 1930 \\ \text { CAR9915 } & 11 & 4522050 & 653350 & 1990 \\ \text { SPL9329 } & 11 & 4522900 & 653900 & 1990 \\ \text { SPL9302 } & 11 & 4522800 & 655350 & 2070 \\ \text { CAR9918 } & 11 & 4523600 & 656500 & 2240 \\ \text { CAR9917 } & 11 & 4524375 & 657200 & 2425\end{array}$


Table 1. Listing of Chainman Formation characteristics with respect to total organic content (TOC), vitrinite reflectance (\% Ro), electrical conductance, hydrocarbon maturity, and hydrocarbon prospectivity pertinent to Bald Mountain profile. Derived from data in Hazlett et al. (1992) and Inan (1993).

\section{NE Nevada Organic Shale Characteristics}

\begin{tabular}{|c|c|c|}
\hline Diamond Range & S. Ruby Mtns & Buck-Butte Mtns \\
\hline $\mathrm{TOC}=0.1-0.3 \div$ & $\mathrm{TOC}=0.3-6.1 \%$ & $\mathrm{TOC}=0.3-6.1 \%$ \\
\hline$\circ \mathrm{Ro}=1.6-2.7$ & $\circ \mathrm{Ro}=1.3-1.6$ & $\circ \mathrm{Ro}=0.3-1.0$ \\
\hline $\begin{array}{l}\mathrm{V} \text {. Conductive } \\
(<3 \text { ohm-m })\end{array}$ & $\begin{array}{l}\text { M. Conductive } \\
(\sim 20 \text { ohm }-\mathrm{m})\end{array}$ & $\begin{array}{l}\text { L. Conductive } \\
\text { (50-100 ohm-m) }\end{array}$ \\
\hline Over-mature & Less Mature & Sub-mature \\
\hline $\begin{array}{l}\text { Low Source Rock } \\
\text { Potential }\end{array}$ & Possible Potential & High Potential \\
\hline
\end{tabular}




\section{FIGURE CAPTIONS}

Figure 1. Generalized location map for the Ruby Mountains region MT survey. Profiles cross Bald Mountain (BMT), Harrison Pass (HRP), Secret Pass (SCP), Cross-Secret (XSC) and Peko Hills $(\mathrm{PKH})$ districts. Inferred Archean-Proterozoic boundary (long dashed arrow) is after Wright and Snoke (1993) and RMT is Roberts Mountain Thrust. Oil exploration wells shown with pluses are Amoco Stageline \#1-A (A-1), Ruby Valley Franklin-1 (F-1), Huntington Valley Pan Am Jiggs-1 (P1), Pine Valley Foreland North Willow 2-27 (W-2), and Diamond Shamrock Kimbark Fed 1-28 (K-1). Bold curve with solid squares along east side of Ruby Mountains is wide-angle seismic survey by University of Wyoming and University of Arizona (Stoerzel and Smithson, 1998; Satarugsa and Johnson, 2000a). Medium curves with open circles are seismic reflection lines of Hauser et al. (1987, COCORP), Valasek et al. (1989), and Stoerzel and Smithson (1998). Pole Canyon is PC and Delcer Buttes is DB. Carlin deposit locations are after Davis and Tingley (1999), with labeled areas R (Rain), G (Gold Quarry), B (Betze-Post), and A (Alligator Ridge-Yankee). Base geology after Stewart and Carlson (1978) and Nutt et al. (2000).

Figure 2. Rose histograms of principal axes of impedances corrected for near-surface 3-D heterogeneity $(\arg Z)$ and of strike directions from vertical-horizontal magnetic field correlations $\left(\operatorname{Re}\left(\mathrm{K}_{\mathrm{z}}\right)\right)$. Strikes are grouped by transect and period band. Average orientation and standard deviation of magnetic field strike and of impedance axis closest to magnetic field strike are given below each histogram. Each histogram contains 300-400 independent estimates.

Figure 3. Two-dimensional inversion resistivity models of the crust for Bald Mountain, Harrison Pass, and Secret Pass transects. Vertical exaggeration is 2:1 in the upper $10 \mathrm{~km}$. Important physiographic locations for Bald Mountain line include Diamond Valley (di), Diamond Mountains (DI), Huntington Valley (hu), Bald Mountain (BA), Mooney Basin (mn), Maverick Springs Range (MV), Long Valley (ln), Butte Mountains (BU), and Butte Valley (bu). Locations for Harrison Pass line include Crescent Valley (cr), Cortez Range (CZ), Pine Valley (pi), Pinon Range (PN), Cedar Ridge (CE), Huntington Valley (hu), Ruby Mountains (RB), Ruby Valley (rb), Medicine Range (ME), and Butte Valley (bu). Locations for Secret Pass line include Humboldt River Valley (hm), Peko Hills (PK), Lamoille Valley (la), Ruby Mountains (RB), Secret Pass (sc), East Humboldt Range (EH), Clover Valley (cv), Spruce Mountain Range (SP) and Independence Valley (in). Starting and a priori 1-D models for each inversion are the same and plotted as a column to the left of each. Thin, rectangular polygonal outline in middle crust on the Harrison Pass section denotes region set to $5000 \mathrm{ohm}-\mathrm{m}$ in alternate inversion discussed with Figure 8.

Figure 4. Observed (left) and computed (right) MT response pseudosections for the Bald Mountain transect of Figures 1 and 3. These plots have horizontal distance as abscissa and log period (T, s) as ordinate for contour plots of response function from each site at each period. The TE (xy) quantities were not used explicitly in the inversion but are computed for qualitative comparison. There is no $\mathrm{K}_{\mathrm{zx}}$ in a $2-\mathrm{D}$ assumption. 
Figure 5. Forward models for the upper crust of the Diamond Range examining precise geometry and properties of Chainman Shales interval. Segment of smoothed inversion model of Bald Mountain section of Figure 3 and observed data appear in upper left. Prefered (best-fit) forward model and computed response is plotted in upper right. Lower left model and response is for Chainman Shales of nearly uniform thickness under eastern Diamond Range. Lower right model and response is for Chainman Shales of essentially equal conductivity across the Diamond Range to central Huntington Valley.

Figure 6. Observed (left) and computed (right) MT response pseudosections for the Harrison Pass transect of Figures 1 and 3. The TE (xy) quantities were not used explicitly in the inversion except for short period TE (xy) phase under Pine Valley and the Pinon Range as marked by the hachured polygon (ticks on side of excluded data). There is no $\mathrm{K}_{\mathrm{zx}}$ in a 2-D assumption.

Figure 7. Typical sounding data from the central Pinon Range where our transect passes through recognized Carlin type deposits. Solid curve is TM (yx) mode response from inversion model of Figure 3, while dashed curve is TE (xy) mode inversion response. TE phase peak around $0.5 \mathrm{~s}$ and apparent resistivity minimum around $2 \mathrm{~s}$ are due to steep conductors flanking resistive body under Pinon Range. Sounding is marked as H43 in Figure 1.

Figure 8. Alternate inversion model for the Harrison Pass transect in which a fairly thin resistive layer is imposed in the middle crust to prevent upper crustal electric current flow from connecting to the lower crust through steep fault zones. Lack of fit typical of central portion of the model is computed for site H06 over core complex rocks (dashed curve) for comparison to the data and the inversion model response of Figure 3 (solid curves).

Figure 9. Observed (left) and computed (right) MT response pseudosections for the Secret Pass transect of Figures 1 and 3. The TE (xy) quantities were not used explicitly in the inversion but are computed for qualitative comparison. There is no $\mathrm{K}_{\mathrm{zx}}$ in a 2-D assumption.

Figure 10. Inversion models with observed and computed pseudosections for the Cross Secret and Peko Hills cross lines over the Secret Pass transect (Figure 1). Symbol 'sc' denotes where the main transect crosses these shorter profiles. See text for selection of data subsets.

Figure 11. Interpreted geological cross sections for upper $20 \mathrm{~km}$ of Bald Mountain, Harrison Pass, and Secret Pass transects incorporating MT resistivity models. Sections are modified from data of Stewart and Carlson (1978), Smith et al. (1991), Newman and Witter (1992), Carpenter et al. (1993a,c), Hansen et al. (1994), Snoke et al. (1997), Nutt et al. (2000), and Satarugsa and Johnson (2000b). RGr is remobilized graphite. Nearby Carlin deposits of Figure 1 are projected onto Harrison Pass cross section. Buried plutons with question marks are interpreted from resistivity. Vertical exaggeration is 2:1 and physiographic locations are as in Figure 3. 


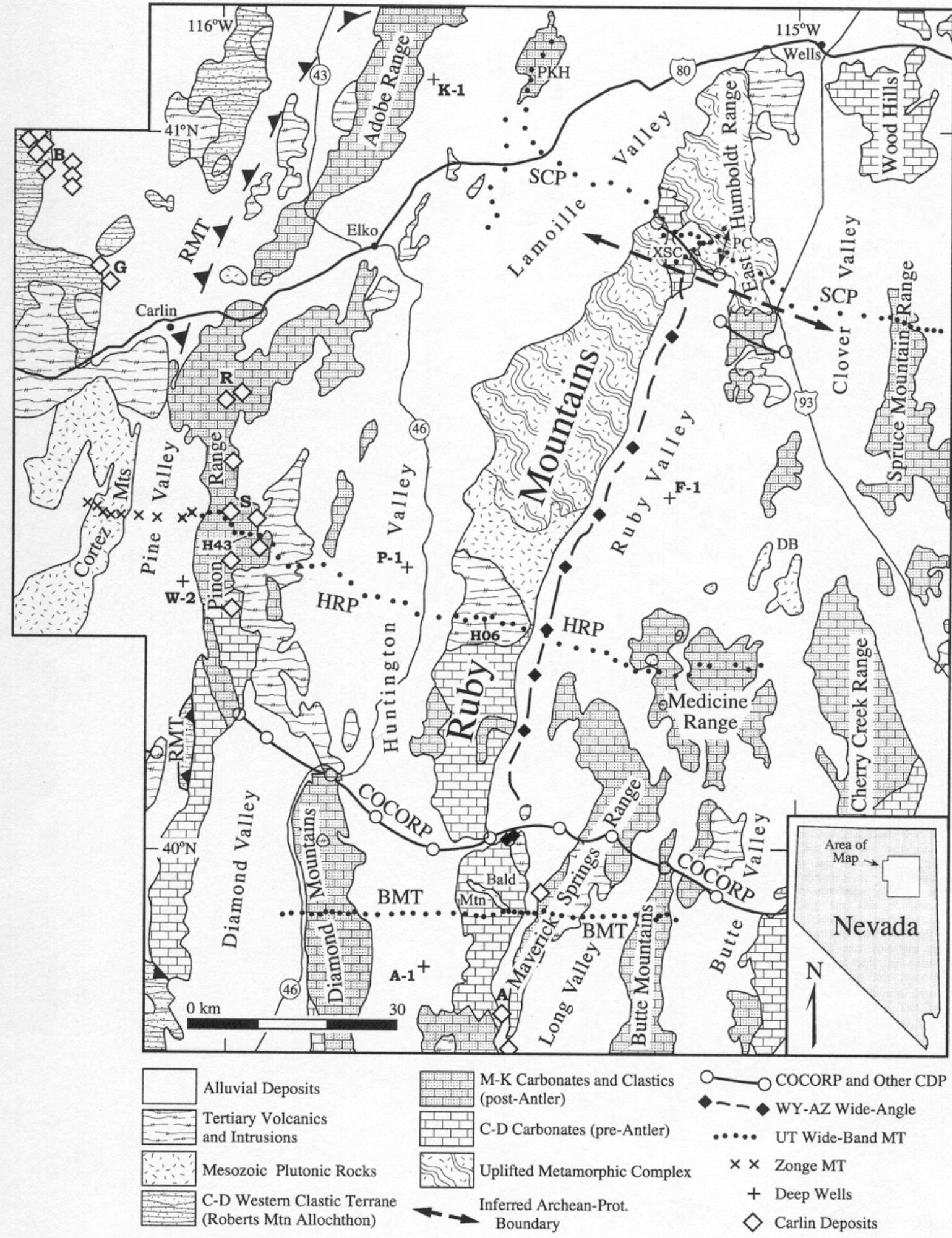

Figure 1. 


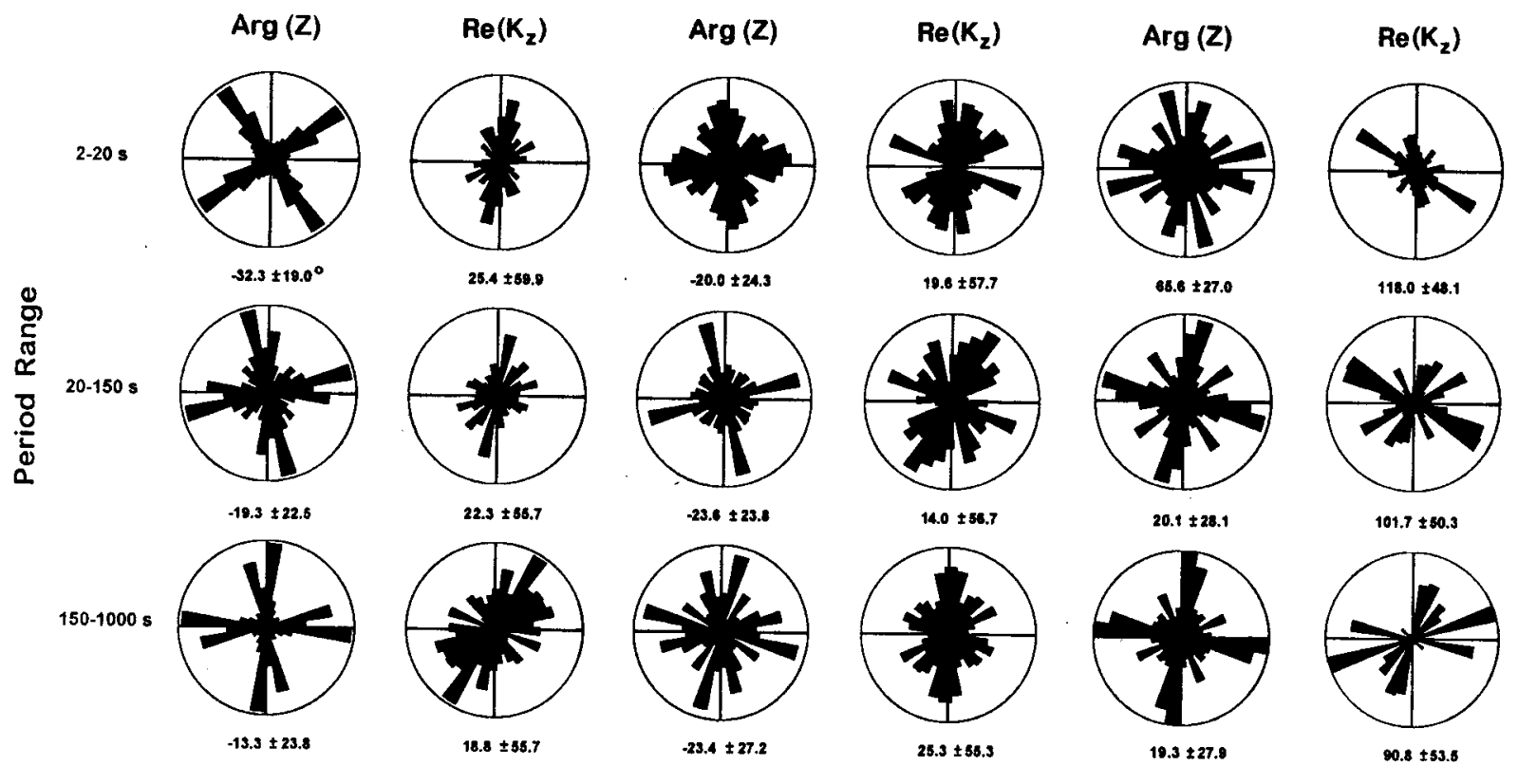

Figure 2. 
E W

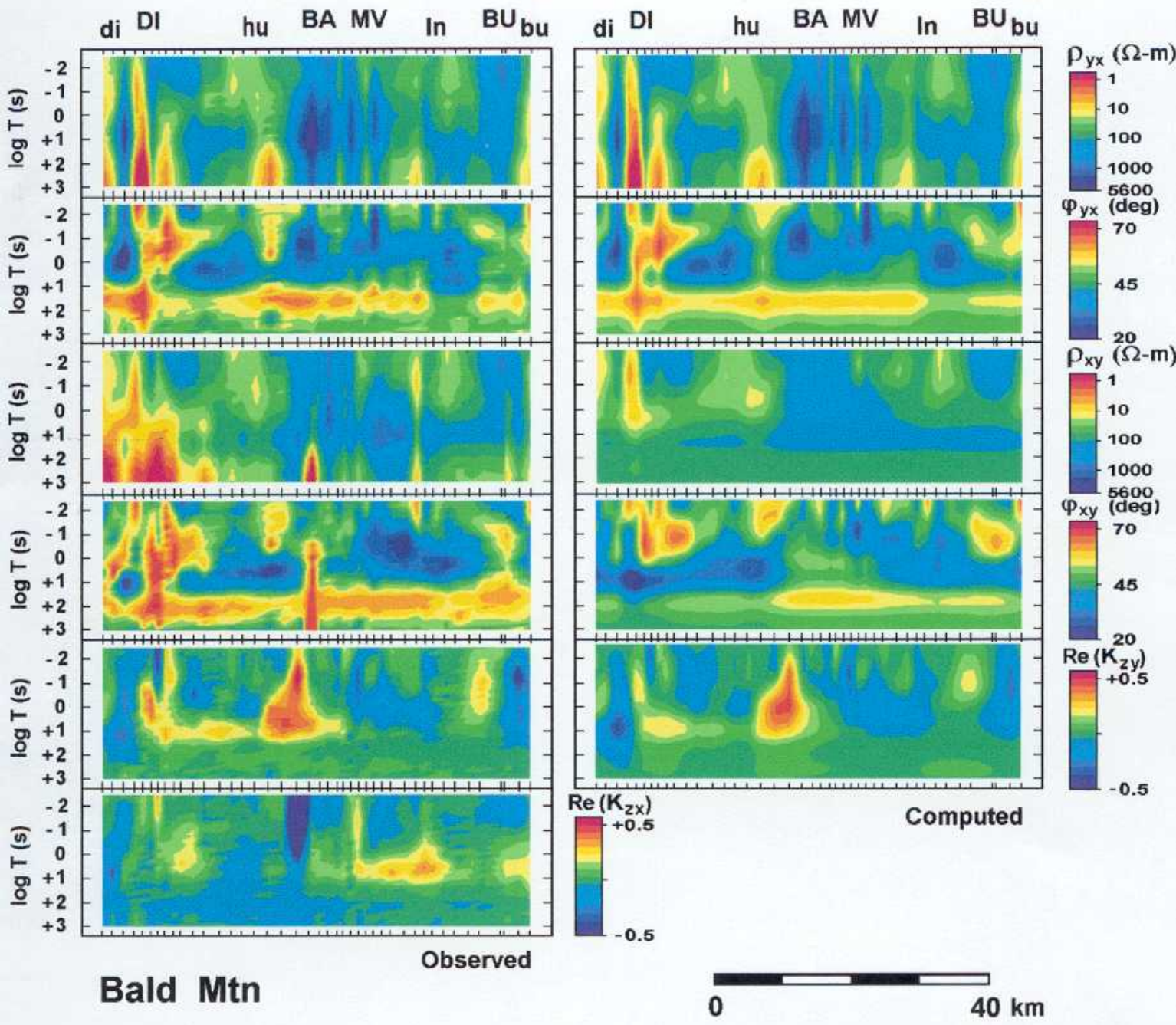

Figure 4. 


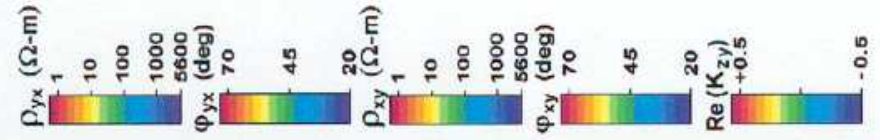

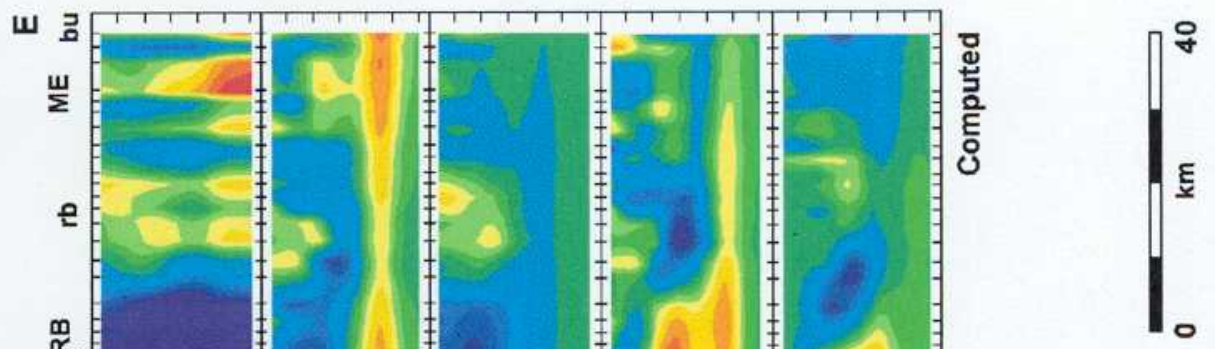

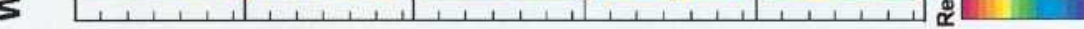

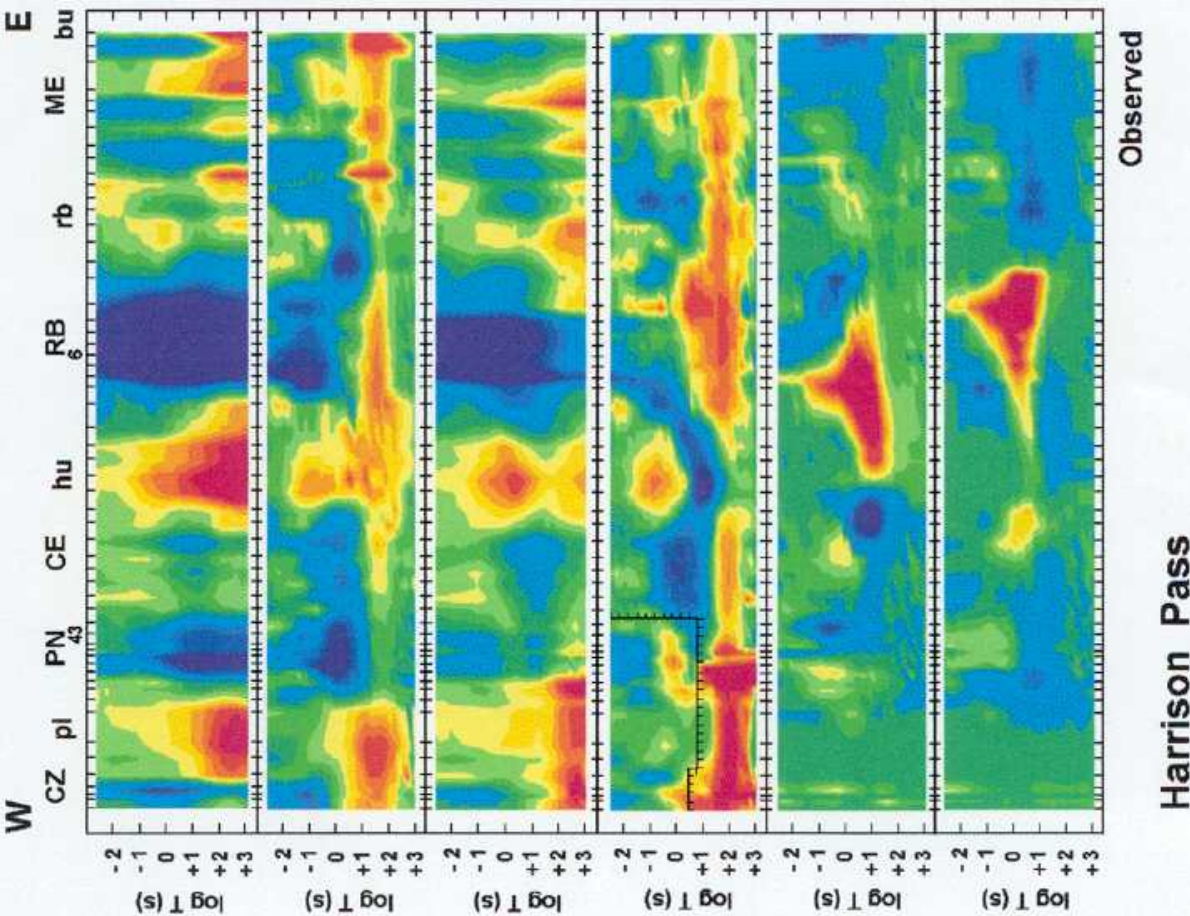

Figure 6. 

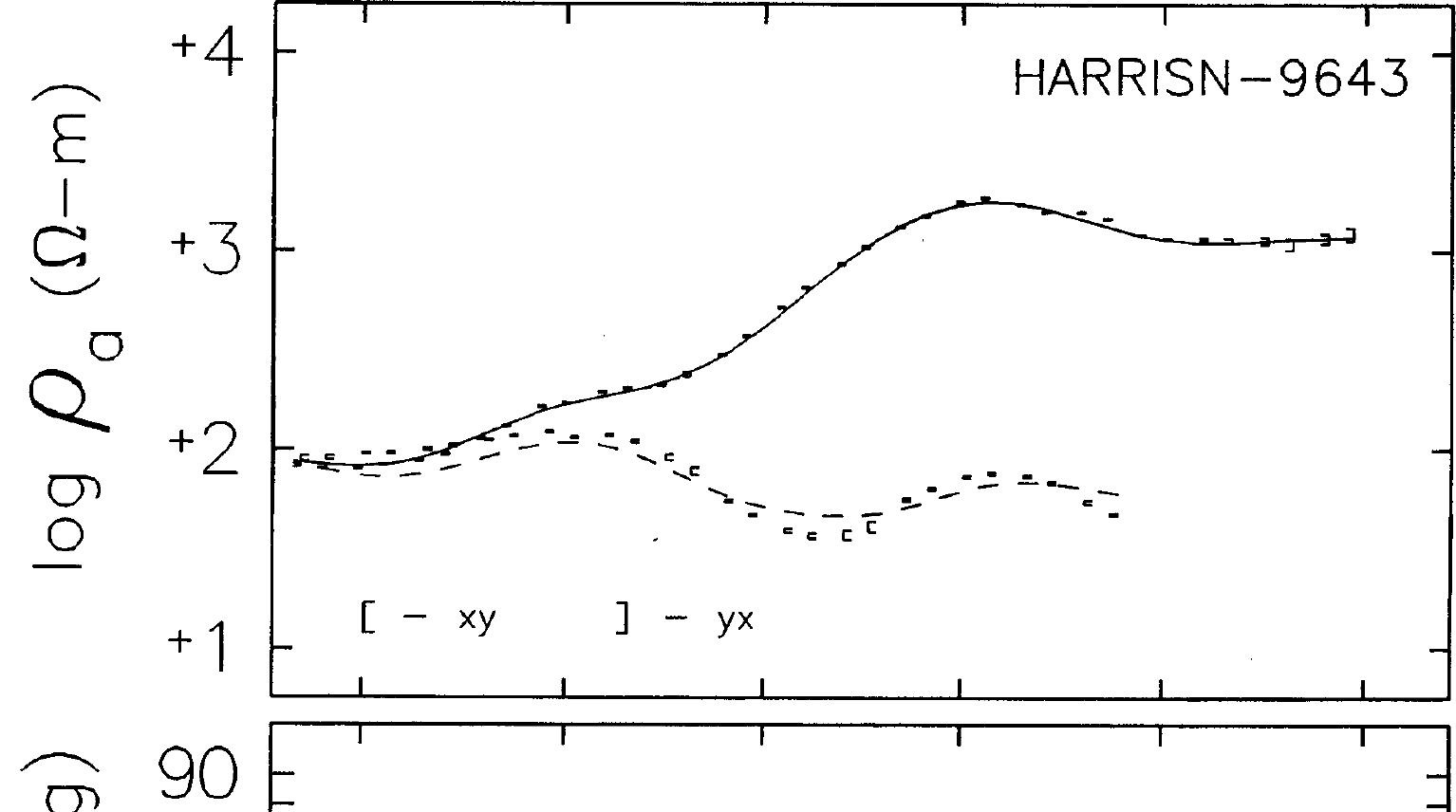

के $90=$

(1) $60=$

\& 30 =

Figure 7.

$\log T$ (s) 
ESE

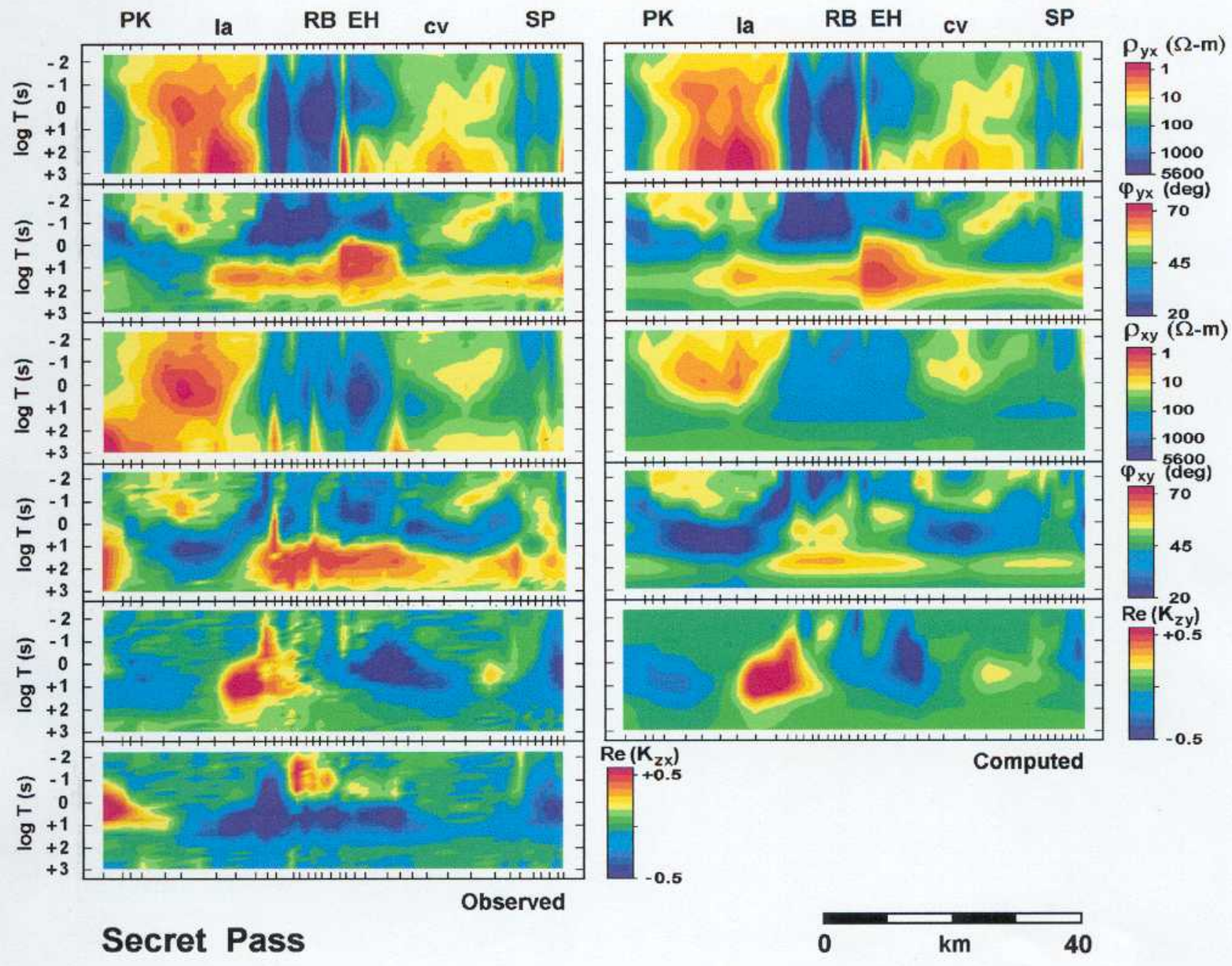

Figure 9. 
